\begin{tabular}{l} 
SCIENCE \& TECHNOLOGY \\
Journal homepage: http://www.pertanika.upm.edu.my/ \\
\hline PERTANIKA
\end{tabular}

\title{
Thermal Comfort Performance of Naturally Ventilated Royal Malaysian Police (RMP) Lockup in Hot and Humid Climate of Malaysia
}

\author{
Bismiazan Abd. Razak ${ }^{1,2 *}$, Mohd. Farid Mohamed ${ }^{1}$, Wardah Fatimah Mohammad \\ Yusoff $^{1}$ and Mohd. Khairul Azhar Mat Sulaiman ${ }^{1}$ \\ ${ }^{1}$ Faculty of Engineering and Built Environment, Universiti Kebangsaan Malaysia, 43600 UKM, \\ Bangi, Selangor, Malaysia \\ ${ }^{2}$ Architecture Branch of the Public Works Department, IPJKR Malaysia, Tingkat 11, Menara Tun Ismail \\ Mohamed Ali (TIMA), Jalan Raja Laut, 50350 Kuala Lumpur, Malaysia
}

\begin{abstract}
Thermal comfort performance of three vacant naturally ventilated Royal Malaysia Police (RMP) case study lockups (LK1 in Penang, LK2 in Melaka \& LK3 in Kuala Lumpur) was measured during monsoon change period from Northeast Monsoon to Southeast Monsoon. According to NGO's report and previous studies, the lockups condition is very poor and hot which contribute to discomfort among detainees. The objectives of the study are to investigate thermal comfort performance of the lockups based on four environmental parameters (Ta, Tr, Va, \& RH) through physical measurement, to predict thermal comfort performance based on operative temperature (To) and neutral operative temperature (Tneutop), and to compare the results with thermal comfort criteria recommended by ASHRAE 55 standard and previous thermal comfort studies in hot and humid climate. The results show that To and Tneutop reading of LK1 is exceeding the maximum range recommended by ASHRAE 55 and previous studies by $2 \%$ to $8 \%$ (To) and $1 \%$ (Tneutop) which categorizing LK1 condition as hot. This is mostly due to high hot airflow brought

ARTICLE INFO

Article history:

Received: 03 February 2021

Accepted: 15 April 2021

Published: 31 July 2021

DOI: https://doi.org/10.47836/pjst.29.3.35

E-mail addresses:

p101088@siswa.ukm.edu.my; bismiazan@gmail.com

(Bismiazan Abd. Razak)

faridmohamed@ukm.edu.my (Mohd. Farid Mohamed)

wardahyusoff@ukm.edu.my (Wardah Fatimah Mohammad Yusoff)

m.khairulazhar@ukm.edu.my (Mohd. Khairul Azhar Mat Sulaiman) through an ineffective window opening. The results will be used as reference for improvement towards some aspects such as window opening, building finishes materials, space volume and building orientation in future lockup design.

Keywords: Hot-humid climate, naturally ventilated buildings, Royal Malaysian Police lockup, Thermal comfort performance
\end{abstract}

* Corresponding author 


\section{INTRODUCTION}

This paper is about study on thermal comfort performance of Royal Malaysia Police (RMP) lockup to understand the lockups internal level of comfort. The study was conducted on three lockups in three different locations which are Penang, Melaka and Kuala Lumpur during monsoon change period from Northeast Monsoon to Southeast Monsoon which is hot and humid. The results obtained from this study will be used to be compared with international standard such as ASHRAE 55 and the result obtained by other previous researcher on the building not limited to the lockup study since there is no study have been conducted on lockup in Malaysia.

Several criteria have been set during selection of the lockup cells for the field study purposes such as the lockup cells must have complete natural ventilation. All fans and exhaust fans were switched off throughout the study period if any. The selected cells for all case study lockups must have close similarities in terms of cell size and finishing to minimize the difference. In addition to this, field study was conducted on vacant lockup cells to understand maximum thermal comfort at zero attendee (default actual maximum thermal comfort measurement).

Although the study was conducted on three case study lockups at three different locations at different day, it will not affect the objective of the study. Results obtained from the three case study lockups will not be compared but will be used to understand each lockup thermal comfort performance based on window openings and space volume factor.

\section{Royal Malaysian Police (RMP) Lockup}

RMP lockup is often associated with guilty individuals or better known as detainees or 'Orang Kena Tangkap' (OKT). It is also known as a place that is bound by various rules, punishments, laws and is categorized as a Prohibited Area and Prohibited Place or 'Kawasan Larangan dan Tempat Larangan' (KLTL) for ordinary people who do not know its actual function and role (PDRM, 1953; SUHAKAM, 2016).

There are two types of RMP lockup namely regular lockup which are available at police stations, and centralized lockup. Both types of lockup have their own function. The regular lockup is only for remand detainees while waiting for the detainees to be taken to court which subsequently serve a sentence in prison. Detainees are usually detained for about a day or not more than 24 hours (PDRM, 1953; Perlembagaan Persekutuan Malaysia, 2010). While the centralized lockup serve to detain detainees for a longer period of time which up to 90 days after being brought to court or during remanded period and this lockup is often used to house detainees involved in serious offenses such as crime, murder, gambling and drugs (SUHAKAM, 2016).

Previous studies on RMP lockup are more qualitative and thematic by using interview, questionnaires and observations as data gathering method. Table 1 shows the previous 
Table 1

Studies related to correctional facilities

\begin{tabular}{|c|c|c|}
\hline Research title & Author & Findings \\
\hline $\begin{array}{l}\text { Deaths in Police Custody } \\
\text { a Thematic Study on } \\
\text { Lock-Up Conditions and } \\
\text { Factors Contributing to } \\
\text { the Death }\end{array}$ & $\begin{array}{l}\text { (SUHAKAM, } \\
\text { 2016) }\end{array}$ & $\begin{array}{l}\text { Studies related to the conditions and factors that contribute } \\
\text { to the death of detainees through qualitative and thematic } \\
\text { methods in interviews and observations on respondents } \\
\text { and study areas. }\end{array}$ \\
\hline $\begin{array}{l}\text { Field study of the indoor } \\
\text { environment in a Danish } \\
\text { prison }\end{array}$ & $\begin{array}{l}\text { (Dogbeh et al., } \\
\text { 2014) }\end{array}$ & $\begin{array}{l}\text { Qualitative and quantitative study of the indoor air quality } \\
\text { of the prison which includes air temperature, relative } \\
\text { humidity, and carbon dioxide factors. } \\
\text { Quantitative - Use of measuring instruments HOBO U12- } \\
012 \text { Temperature/Relative Humidity/ Light/External Data } \\
\text { Logger dan Vaisala GMW22 Carbon Dioxide. } \\
\text { Qualitative - Use of interview scheme and questionnaire } \\
\text { based on ASHRAE-7 standard scale on respondents. }\end{array}$ \\
\hline $\begin{array}{l}\text { Added Value to Security } \\
\text { Building Design Case } \\
\text { Study: Police Station in } \\
\text { Malaysia }\end{array}$ & $\begin{array}{l}\text { (Zaharin et al., } \\
\text { 2019) }\end{array}$ & $\begin{array}{l}\text { Qualitative study related to design planning and layout of } \\
\text { RMP police station facilities that meet standard operating } \\
\text { procedures (SOP) through observation methods of case } \\
\text { studies, scientific studies, interviews, and semi-structured } \\
\text { questionnaires on respondents. }\end{array}$ \\
\hline $\begin{array}{l}\text { Research on the Design } \\
\text { Typology of the Royal } \\
\text { Malaysian Police (RMP) } \\
\text { Lockups }\end{array}$ & $\begin{array}{l}\text { (Razak et al., } \\
2020 \text { ) }\end{array}$ & $\begin{array}{l}\text { Qualitative study related to the typology of the Royal } \\
\text { Malaysian Police (RMP) Lockups through case studies } \\
\text { and literature review studies on the design of existing } \\
\text { security agency lockups. }\end{array}$ \\
\hline
\end{tabular}

studies conducted on rehabilitation facilities building such as lockup and prison locally and globally.

Referring to Table 1, study by SUHAKAM (2016) was qualitative or thematic based on observations and interviews conducted. No measurement instruments at the studied site were scientifically recorded. While the study conducted by Dogbeh et al. (2014) was focusing on qualitative and quantitative study on Indoor Air Quality (IAQ) which include air temperature, relative humidity and carbon dioxide factor. The study by Zaharin et al. (2019) was related to the RMP police station's design and facilities layout planning which coincide with RMP Standard Operating Procedure (SOP) through observation methods of the case studies, scientific studies, interviews and semi-structured questionnaires on respondents. Slightly different in terms of focused subject on study Razak et al. (2020) which it is more to the presentation of information related to the typology of lockup design based on scientific studies, case studies and preliminary analysis. Additionally, no scientific physical measurement instruments related to natural ventilation and RMP lockup thermal comfort were used in the abovementioned studies.

Common issues highlighted by Non-Government Organization (NGO) such as Malaysian Human Rights Commission (SUHAKAM) are natural ventilation which might cause by inefficient window design. Referring to Figure 1, majority of the opinion is on poor 


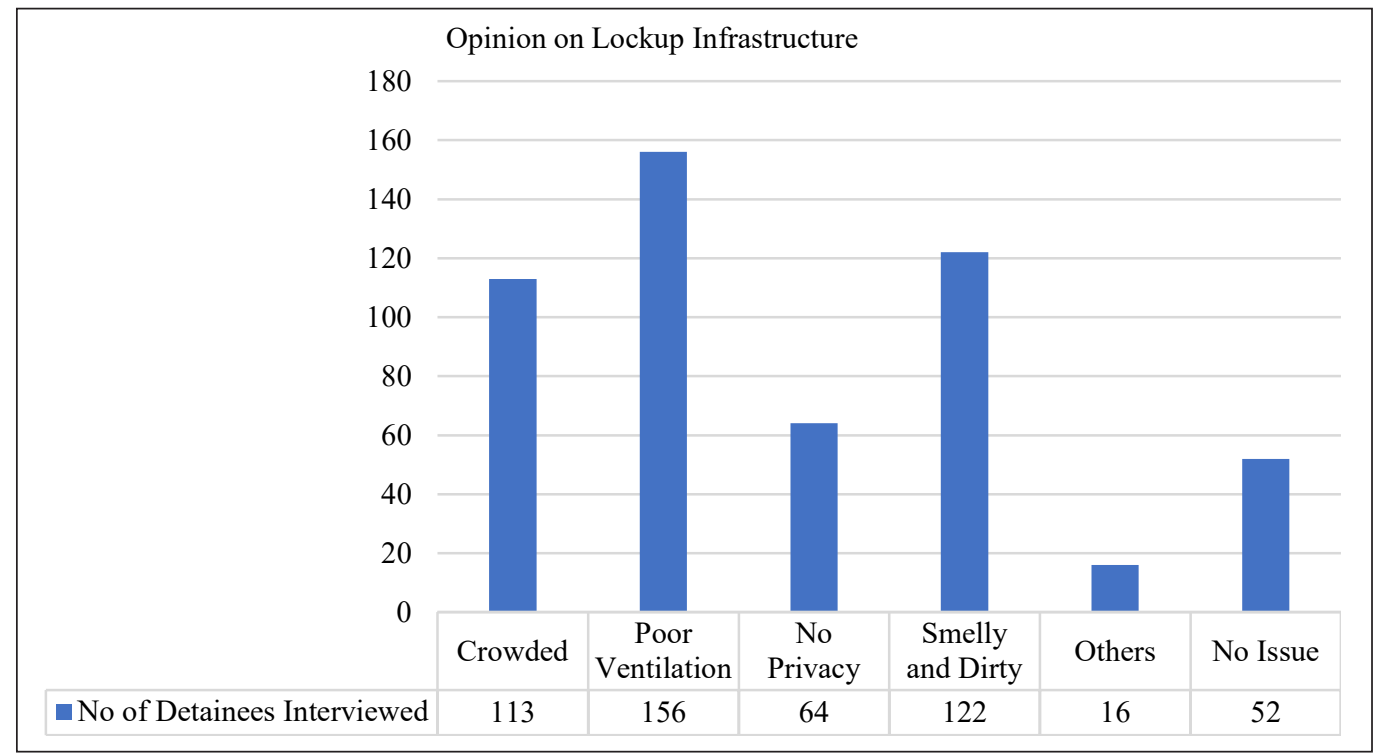

Figure 1. Opinion on lockup cell infrastructure Source: (SUHAKAM, 2016)

ventilation with 156 opinions from the detainees. The condition of the lockup is described as hot which contribute to the discomfort among detainees (SUHAKAM, 2016). Based on the statement of the Nelson Mandela Rules, every detainee should be provided with a facility that meets physical and mental needs considering environmental factors such as ventilation (SUHAKAM, 2016). According to Dogbeh et al. (2014), most detainees feel dissatisfied with the thermal comfort and air quality of the indoor environment caused by the lack of ventilation and excessive direct sunlight into the detention space.

However, most studies conducted previously are too brief without proper measurement and analysis to understand further on the contributing factor to the lockups condition. Hence it shows a need to have a field study through physical measurement by using appropriate instrument on the problematic lockup highlighted by the NGO.

The objectives of the study are to investigate lockup thermal comfort performance based on four environmental parameters (Ta, Tr, Va, \& RH) through physical measurement of field study, to predict thermal comfort performance based on the adaptive model indices Operative Temperature (To) and Neutral Operative Temperature (Tneutop), and to compare the results with thermal comfort criteria recommended by ASHRAE 55 and previous thermal comfort studies in hot and humid climate.

\section{Malaysia Climate}

Climate conditions are major influence factor to the design of a building which is close related to the user comfort as well as complying with the efficient construction criteria 
(Tharim et al., 2018). Malaysia is well known with the hot and humid climate with minimum annual average temperature between $23.7^{\circ} \mathrm{C}$ to $26.4^{\circ} \mathrm{C}$ and maximum annual average temperature between $26.4^{\circ} \mathrm{C}$ to $31.3^{\circ} \mathrm{C}$ with an average minimum daily temperature between $23.0^{\circ} \mathrm{C}$ to $29.0^{\circ} \mathrm{C}$ and maximum daily temperature between $34.0{ }^{\circ} \mathrm{C}$ to $36.9^{\circ} \mathrm{C}$. Malaysia experience high relative humidity rate throughout the year between $40 \%$ to $90 \%$. The average annual rainfall distribution rate is between $2000 \mathrm{~mm}$ to $2500 \mathrm{~mm}$ which makes Malaysia as a country with a relatively high rainfall distribution rate. Malaysia average annual rate of sunlight reception is between 6 to 7 hours a day which is categorized as high compared to other countries given that Malaysia position surrounded by oceans (Jabatan Meteorologi Malaysia, 2020). As a result, it is quite difficult to achieve an efficient level of thermal comfort through natural ventilation in hot and humid climate region.

\section{Thermal Comfort}

Thermal comfort is defined as a condition in which the mind describes satisfaction with the thermal environment and it is assessed by subjective assessment (ASHRAE 55, 2017; Yang \& Clements-Croome, 2018). Zhang et al. (2007) stated that thermal comfort is a condition associated with the thermal environment satisfaction. The interaction of human terms with the environment involves physical and psychological responses. Thermal interaction between human and surrounding area involves physical and psychological response. This shows that thermal comfort is closely related to the human mind, physical and psychological factor through response towards surrounding environment.

According to building science, thermal comfort is defined as the balance of heat transfer between human and their environmental condition (Tang \& Chin, 2017). Thermal comfort can also be influenced by the interaction between the building and the surrounding environment (Tharim et al., 2018). While general perception of thermal comfort is a condition where human mind, physical and psychological respond to the balance of heat transfer influenced by factors such as internal and external environment of the building and human body condition which are very subjective to be measured.

Ventilation through an efficient window's opening either by cross ventilation or stack effect approach as well as a combination of other passive ventilation systems are able to ensure thermal comfort factors such as air temperature, air speed, air humidity and temperature radiation are achieved (Gharakhani et al., 2014). This thermal comfort can also be achieved and experienced regardless of types of clothing worn and individual metabolism rate during any of activities carried out by individual.

However, it is not as easy as expected because natural ventilation with hot and humid climates throughout the year is highly dependent on the surrounding condition (Jiang et al., 2003) such as air speed and wind pressure to bring fresh air into the building to replace existing air, reduce humidity and provide sufficient ventilation in the building. This has 
been a great challenge to Architects and Engineers in Malaysia to design a building that can meet all criteria especially on efficient ventilation and high thermal comfort as well as providing a healthy and well perform environment to the user apart from efficient energy consumption (Azizpour et al., 2013; Chan et al., 2013).

Factors Affecting Thermal Comfort. According to ASHRAE 55 (2017), thermal comfort can be influenced by two factors which are physical (environmental) and individual (personal) factor. Physical factor consists of air temperature, air speed, relative humidity and mean radiant temperature. While individual factor consists of metabolic rates and clothing. Meanwhile Al-Absi \& Abas (2018) stated that other contributing factors such as perception, acclimatize (Azizpour et al., 2011), experience, age and gender, health conditions, food and drink as well as body shape are also categorized as the third influencing factors to the thermal comfort. All these factors can change according to the time and conditions of the environment as well as individual. In other words, it is difficult to achieve full satisfaction of thermal comfort due to various factors.

A building is designed and built to suit the user's needs, comfortability and criteria (Nordin et al., 2017). As a shelter, a place to carry out activities such as work, leisure, and rest, a building must meet the criteria needed by the users including comfortable, conducive and safe while living in it (Davies \& Jokiniemi, 2008; Tharim et al., 2018). A good design concept should emphasize selection of appropriate site (Chan et al., 2013), best orientation and space (Xue et al., 2016), appropriate materials and finishes (Yusoff \& Mohamed, 2017), adequate ventilation and lighting as well as appropriate facilities (Xue et al., 2016). All the above criteria are considered best practice for design and built for all types of building including facilities for national security agencies such as the Royal Malaysian Police (RMP) lockup which houses a huge number of detainees.

Table 2 shows summary of previous thermal comfort studies of naturally ventilated building in hot and humid region for various types of building.

Apart from the studies stated in Table 2, other studies related to thermal comfort for naturally ventilated building that have been conducted by previous researchers are more towards residential (Attia \& Carlucci, 2015; Han et al., 2007; Kubota et al., 2009; Nur'aini, 2017; Taweekun \& Tantiwichien, 2013; Wong et al., 2020), office building (Aminuddin et al., 2012; Damiati et al., 2016), educational facilities such as classroom, kindergarten and hostel (Dahlan et al., 2008; Fabbri, 2013; Kamaruzzaman \& Tazilan, 2013). So far there is no thermal comfort study and field investigation have been conducted on correctional facilities especially police lockup in hot and humid climate region. Since there is no reference related to the naturally ventilated correctional facilities in hot and humid climate region, the findings and results obtained from the studies in Table 2 and others are still relevant to be used as reference and guideline for the present study. 
Table 2

Summary of previous thermal comfort studies of naturally ventilated building in hot and humid region

\begin{tabular}{|c|c|c|c|c|c|}
\hline Author & Country & $\begin{array}{l}\text { Koppen } \\
\text { Climate }\end{array}$ & $\begin{array}{r}\text { Type of } \\
\text { building }\end{array}$ & $\begin{array}{l}\text { Type of } \\
\text { study }\end{array}$ & $\begin{array}{c}\text { Temperature of comfort / } \\
\text { range }\left({ }^{\circ} \mathrm{C}\right)\end{array}$ \\
\hline $\begin{array}{l}\text { (Webb, } \\
\text { 1959) }\end{array}$ & Singapore & $\begin{array}{l}\text { Tropical } \\
\text { Rainforest }\end{array}$ & Buildings & Field study & $\begin{array}{l}26.0^{\circ} \mathrm{C} \\
\text { Optimum value (thermally } \\
\text { comfort) }\end{array}$ \\
\hline $\begin{array}{l}\text { (de Dear et } \\
\text { al., 1991) }\end{array}$ & Singapore & $\begin{array}{l}\text { Tropical } \\
\text { Rainforest }\end{array}$ & $\begin{array}{l}\text { High rise } \\
\text { residential } \\
(\mathrm{NV}) \text { and office } \\
\text { building (AC) }\end{array}$ & $\begin{array}{l}\text { Field } \\
\text { experiments }\end{array}$ & $\begin{array}{l}29.6^{\circ} \mathrm{C} \\
\text { Neutral temperature (NT) } \\
\text { Operative temperature (To) } \\
(\mathrm{NV})\end{array}$ \\
\hline $\begin{array}{l}\text { (de Dear } \\
\text { \& Brager, } \\
\text { 2002) }\end{array}$ & $\begin{array}{l}\text { Thailand, } \\
\text { Indonesia, } \\
\text { Singapore }\end{array}$ & $\begin{array}{l}\text { Tropical } \\
\text { Monsoon } \\
\text { Tropical } \\
\text { Rainforest } \\
\text { Tropical } \\
\text { Rainforest }\end{array}$ & Office & Field study & $\begin{array}{l}26.0-27.0^{\circ} \mathrm{C}\left(26.7^{\circ} \mathrm{C}\right) \\
\text { Neutral temperature }(\mathrm{NT})(\mathrm{NV})\end{array}$ \\
\hline $\begin{array}{l}\text { (Wong \& } \\
\text { Khoo, 2003) }\end{array}$ & Singapore & $\begin{array}{l}\text { Tropical } \\
\text { Rainforest }\end{array}$ & Classroom & Field Study & $\begin{array}{l}28.8^{\circ} \mathrm{C} \\
\text { Neutral temperature (NT) }\end{array}$ \\
\hline $\begin{array}{l}\text { (Feriadi \& } \\
\text { Wong, 2004) }\end{array}$ & Indonesia & $\begin{array}{l}\text { Tropical } \\
\text { Rainforest }\end{array}$ & Residential & Field study & $\begin{array}{l}29.2^{\circ} \mathrm{C} \\
\text { Operative temperature (To) } \\
29.9^{\circ} \mathrm{C} \text { Effective temperature } \\
\left(\mathrm{ET}^{*}\right)\end{array}$ \\
\hline $\begin{array}{l}\text { (Zain et al., } \\
\text { 2007) }\end{array}$ & Malaysia & $\begin{array}{l}\text { Tropical } \\
\text { Rainforest }\end{array}$ & Residential & Field study & $\begin{array}{l}30.9^{\circ} \mathrm{C} \\
\text { Operative temperature (To) }\end{array}$ \\
\hline $\begin{array}{l}\text { (Djamila et } \\
\text { al., 2013) }\end{array}$ & Malaysia & $\begin{array}{l}\text { Tropical } \\
\text { Rainforest }\end{array}$ & Residential & Field study & $\begin{array}{l}30.2{ }^{\circ} \mathrm{C} \\
\text { Neutral Temperature (NT) }\end{array}$ \\
\hline $\begin{array}{l}\text { (Toe \& } \\
\text { Kubota, } \\
\text { 2013) }\end{array}$ & Malaysia & $\begin{array}{l}\text { Tropical } \\
\text { Rainforest }\end{array}$ & Buildings & Field study & $\begin{array}{l}\text { Neutral operative temperatures } \\
24.9-31.2^{\circ} \mathrm{C} \text { (hot-humid) } \\
24.8-33.7^{\circ} \mathrm{C} \text { (hot-dry) } \\
19.0-24.7^{\circ} \mathrm{C} \text { (moderate } \\
\text { climates) }\end{array}$ \\
\hline
\end{tabular}

Thermal Comfort Evaluation Model. There are two thermal comfort models that are often used by previous researchers to measure the thermal comfort performance of a building which are static model and adaptive model. Static model depends on the controlled environmental conditions (steady-stated condition). Adaptive model is more focused on field studies with a combination of surveys of respondents and also studies on thermal comfort variable (Maarof, 2014). For the present study purpose, adaptive model by using operative temperature and neutral operative temperature indices is implemented.

Adaptive Model - Operative Temperature (To) and Neutral Operative Temperature (Tneutop). Adaptive model relates with indoor temperature or acceptable temperature ranges to climatological parameters or outdoor thermal environmental variable especially for naturally ventilated building (de Dear \& Brager, 2002; Toe \& Kubota, 2013) and also 
fundamental of physics and physiology factors (ASHRAE 55, 2017; de Dear \& Brager, 2002). These factors are important for adaptive models in determining expectations and perceptions of thermal perception by the occupants (de Dear \& Brager, 2002). Various adaptive indices have been used by previous researchers in determining comfort condition in their study such as Operative Temperature (To), Effective Temperature (EF*), Standard Effective Temperature (SET), Equatorial Thermal Index (ETI), Adaptive Comfort Standard (ACS) and more.

In the present study, operative temperature (To) indices is used to calculate and analyze the mean radiant temperature reading $(\mathrm{Tr})$ results obtained through physical measurement from the globe temperature ( $\mathrm{Tg}$ ) (50 mm diameter black globe thermometer probe) in case study lockup according to ASHRAE 55 (López-Pérez et al., 2019). Various equations have been introduced by the previous researcher in the calculations of operative temperature. According to ASHRAE 55 method, Equation 1 was used to calculate operative temperature.

To $\quad=\mathrm{ATa}+(1-\mathrm{A}) \mathrm{Tr}$

Where

To = operative temperature

$\mathrm{Ta}=$ average air temperature

$\operatorname{Tr} \quad=$ mean radiant temperature

A can be selected from the following values as a function of the average air speed $\mathrm{Va}$ $(\mathrm{Va}<0.2 \mathrm{~m} / \mathrm{s}$

$(\mathrm{A}=0.5)$, Va $0.2 \mathrm{~m} / \mathrm{s}$ to $0.6 \mathrm{~m} / \mathrm{s}(\mathrm{A}=0.6)$, Va $0.6 \mathrm{~m} / \mathrm{s}$ to $1.0 \mathrm{~m} / \mathrm{s}(\mathrm{A}=0.7)$

Operative temperature was then analyzed by using a new adaptive equation produced by Toe \& Kubota (2013) which is Neutral Operative Temperature (Tneutop). Neutral operative temperature equation was chosen based on a comprehensive study and analysis through meta-analysis of the ASHRAE RP-884 database with reference to two major adaptive standard which are ASHRAE and BSI EN 15251. Both are developed specifically for naturally ventilated building in countries with hot and humid climate such as Malaysia. This equation is also formulated by considering prevailing outdoor air temperature, indoor air speed and relative humidity. Therefore, the Tneutop determined by Equation 2 is more suitable for the present study.

Tneutop $=0.57$ Toutdm +13.8

Where

Tneutop = indoor neutral operative temperature

Toutdm = daily mean outdoor air temperature 


\section{METHODS}

\section{Case Study Lockups}

The case study lockups details are shown in Table 3 and Figure 2. The lockups were recommended by RMP based on previous findings by SUHAKAM.

Table 3

Case study lockup background

\begin{tabular}{|c|c|c|}
\hline $\begin{array}{c}\text { Case study } \\
\text { lockup }\end{array}$ & State Police District & Background \\
\hline $\begin{array}{l}\text { LK1 } \\
\text { Jalan Patani }\end{array}$ & $\begin{array}{l}\text { North East District } \\
\text { Police Headquarters, } \\
\text { Penang. } \\
\text { (Figure 2a) }\end{array}$ & $\begin{array}{l}\text { Single storey building consists of } 14 \text { cells with two different } \\
\text { capacity: } 3 \text { or } 6 \text { detainees per cell. LK1 main purpose is to } \\
\text { temporarily house male detainees as well as foreign detainees } \\
\text { before being remanded in court. }\end{array}$ \\
\hline $\begin{array}{l}\text { LK2 } \\
\text { Alor Gajah }\end{array}$ & $\begin{array}{l}\text { Alor Gajah District } \\
\text { Police Headquarters, } \\
\text { Melaka. } \\
\text { (Figure 2b) }\end{array}$ & $\begin{array}{l}\text { Located on the ground floor of two-storey building. It consists } \\
\text { of } 11 \text { adult male detention cells, } 3 \text { female detention cells and } 2 \\
\text { juvenile detention cells. All cells are capable to accommodate } \\
\text { between } 1 \text { to } 3 \text { prisoners at a time. Gazetted in 2001, LK2 } \\
\text { serves as a centralized lockup and temporary place for } \\
\text { detainees before being remanded in court. }\end{array}$ \\
\hline $\begin{array}{l}\text { LK3 } \\
\text { Jinjang Kuala } \\
\text { Lumpur } \\
\text { Central }\end{array}$ & $\begin{array}{l}\text { Sentul District Police } \\
\text { Headquarters, Federal } \\
\text { Territory of Kuala } \\
\text { Lumpur } \\
\text { (Figure 2c) }\end{array}$ & $\begin{array}{l}\text { A three-story building that almost exclusively serves as lockup } \\
\text { with various size and type of cells for male, female, and even } \\
\text { juvenile detainees. LK3 consists of a cell designed for } 3,6 \text { or } \\
9 \text { detainees. LK3 main purpose is to house detainees before } \\
\text { being remanded in court as well as housing serious offenders } \\
\text { facing serious criminal cases such as drug, gambling, human } \\
\text { trafficking and gangsterism. }\end{array}$ \\
\hline
\end{tabular}

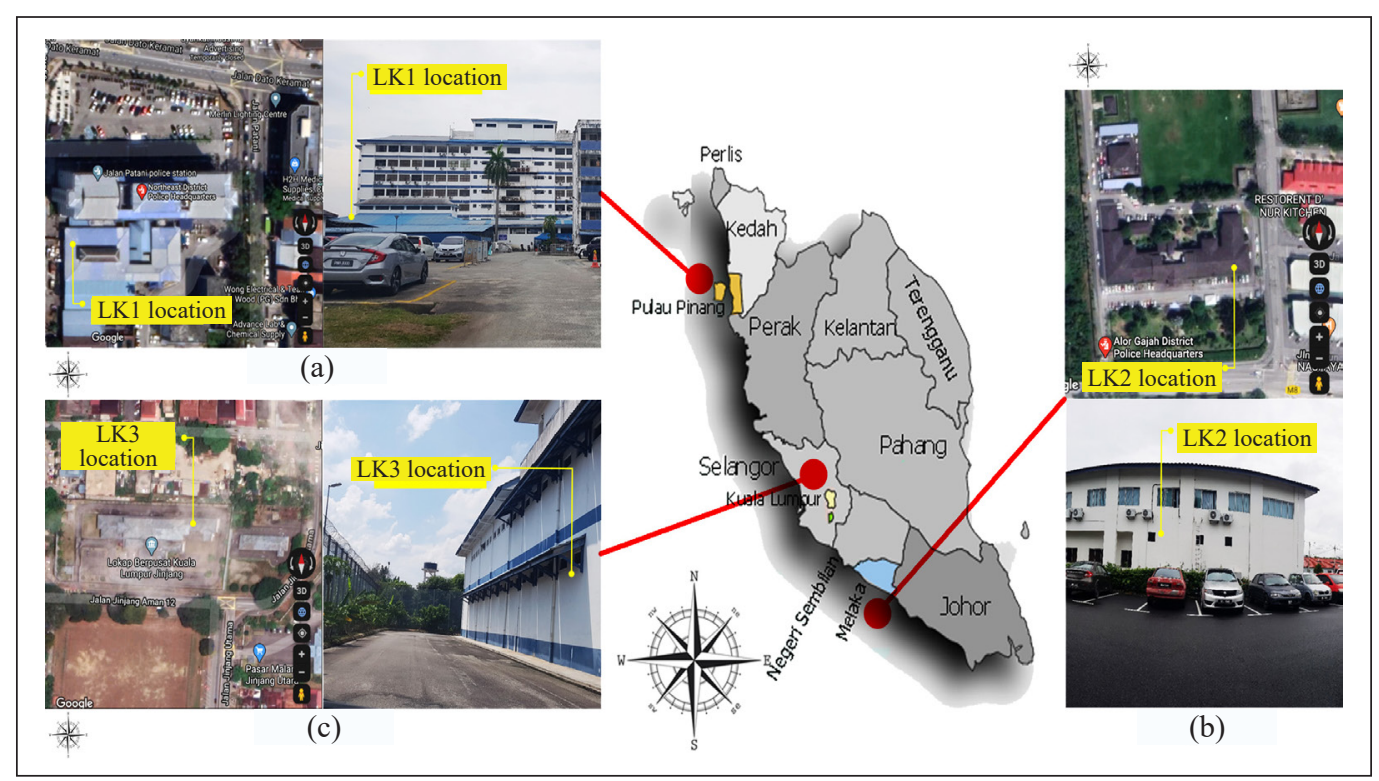

Figure 2. Site and building of the case study lockups: (a) LK1; (b) LK2; (c) LK3 
Table 4 shows a summary of the case study lockups location, conceptual floor plan, conceptual section and measuring instrument location (LK1, LK2 and LK3). Table 5 shows a summary of information related to case study lockup (LK1, LK2 and LK3).

\section{Physical Measurement Duration}

Physical measurements were carried out between March and August 2020, during monsoon change where Malaysia experience a relatively dry season with wind speeds of less than 15 knots $(7.7 \mathrm{~m} / \mathrm{s})($ Jabatan Meteorologi Malaysia, 2020). The average daily temperature during this period of time is considered high which is between $31.2^{\circ} \mathrm{C}$ to $33.2^{\circ} \mathrm{C}$ (World Meteorological Organisation, 2020). Physical measurement at this point of time is strongly recommended to understand better on thermal comfort of the lockups in hot and humid climate region (Gharakhani et al., 2014; Xue et al., 2016).

The physical measurements were carried out from 15 to 20 March 2020 for LK1, 20 to 25 July 2020 for LK3 and on 27 July to 1 August 2020 for LK2. This physical measurement was conducted 24 hours of 5 consecutive days. One hour a day was allocated for data collection, battery change and device reset. The total rainfall distribution recorded for the three case study lockups is minimal during the physical measurement period.

\section{Physical Measurement Instrument}

Two types of appropriate instruments which comply to the ISO 7726 requirement (ASHRAE $55,2017)$ were used to measure four environmental parameters which are air temperature (Ta), mean radiant temperature ( $\mathrm{Tr}$ ), air speed (Va) and relative humidity (RH). Delta Ohm Thermocouple Infrared Thermometer HD32.23 WBGT-PMV was used to measure indoor parameters and Seven Elements Integrated Weather Sensor WTS700 was used to measure outdoor parameters. Summary of instruments, parameters measuring ranges and recording method are demonstrated in Table 6 and Figure 3.

All physical measurement instrument used are calibrated to ensure that data collected are accurate and to avoid any data discrepancy.

\section{Physical Measurement Procedure and Evaluation of Thermal Comfort Performance}

Following Class I field research protocol (Maarof, 2014), three sets of Delta Ohm Thermocouple Infrared Thermometer HD32.23 WBGT-PMV instrument with three different height of leveling from the floor were placed inside the lockup to measure indoor thermal comfort performance. All physical measuring instruments used in this study follow ASHRAE Standard 70 or 113 or ISO 7726. As stated in Table 7, the physical measuring instruments have been placed at the center of the bed (center of the lockup) as it is the main area which usually occupied by the detainees especially for sleeping, sitting, and standing 
Thermal Comfort Performance of Royal Malaysian Police (RMP) Lockup

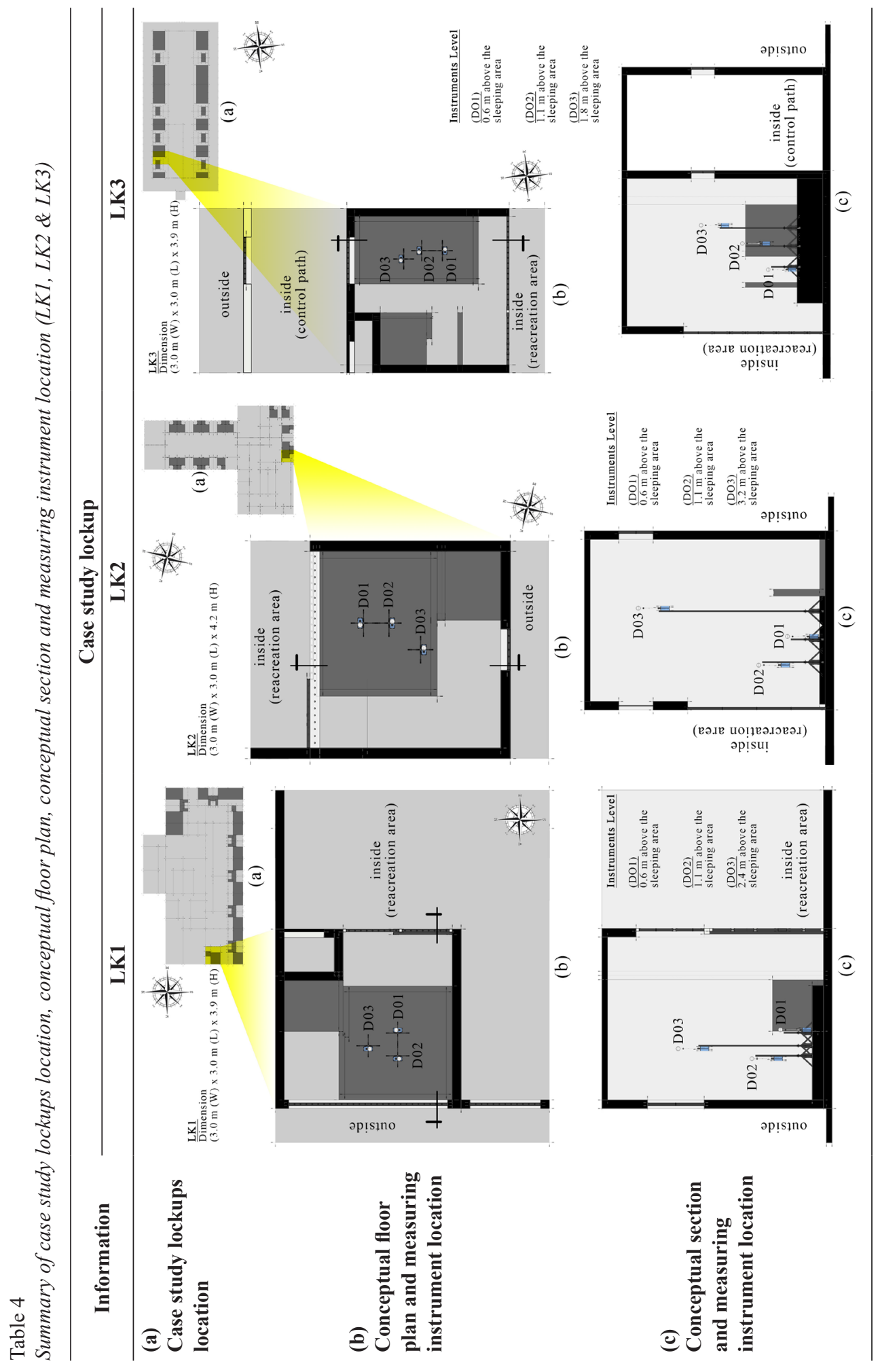

Pertanika J. Sci. \& Technol. 29 (3): 1627 - 1654 (2021) 


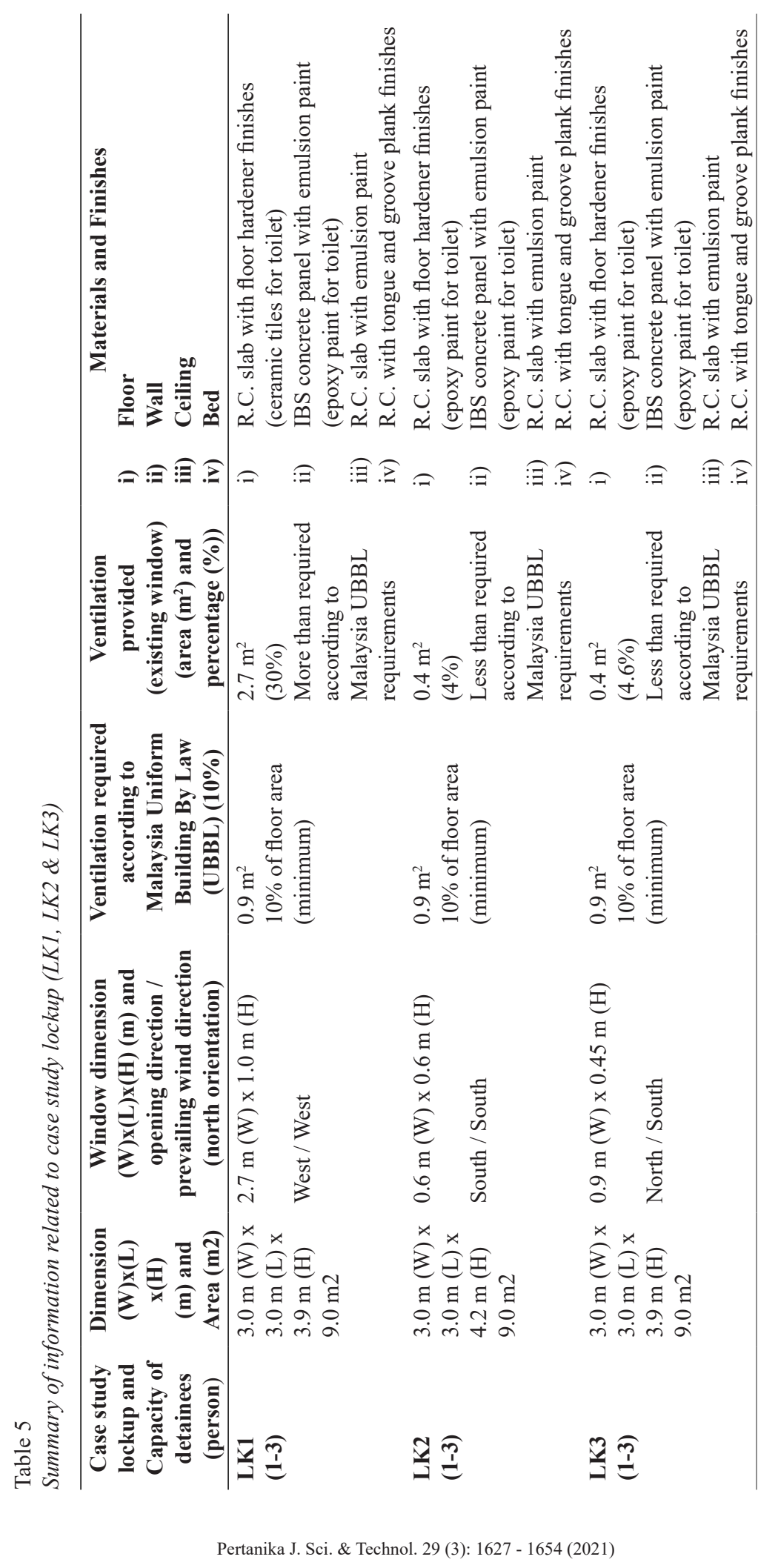


Table 6

Summary of instrument, parameters measuring ranges and accuracy

\begin{tabular}{|c|c|c|c|c|}
\hline Instrument & Unit / Set & Parameters & Measuring ranges & Accuracy \\
\hline \multicolumn{5}{|l|}{ Indoor Parameters } \\
\hline $\begin{array}{l}\text { Delta Ohm Thermocouple } \\
\text { Infrared Thermometer } \\
\text { HD 32.3 WBGT-PMV } \\
\text { Probe: AP 3203.2 } \\
\text { Probe: AP 3217.2 } \\
\text { Probe: AP 3217.2 }\end{array}$ & $\begin{array}{l}3 \\
(\mathrm{DO} 1, \mathrm{DO} 2, \\
\text { DO3) }\end{array}$ & $\begin{array}{l}\text { Air temperature } \\
\text { Air speed } \\
\text { Relative humidity } \\
\text { Globe temperature }\end{array}$ & $\begin{array}{l}0^{\circ} \mathrm{C} \text { to } 100^{\circ} \mathrm{C} \\
0 \text { to } 5 \mathrm{~m} / \mathrm{s} \\
5 \% \text { to } 98 \% \\
-10{ }^{\circ} \mathrm{C} \text { to } 100{ }^{\circ} \mathrm{C}\end{array}$ & $\begin{array}{l}\text { Class } 1 / 3 \text { Din } \\
\pm 0.05 \mathrm{~m} / \mathrm{s} \\
\pm 2.5 \% \\
\text { Class } 1 / 3 \text { Din }\end{array}$ \\
\hline \multicolumn{5}{|l|}{ Outdoor Parameters } \\
\hline $\begin{array}{l}\text { Seven Elements Integrated } \\
\text { Weather Sensor WTS700 }\end{array}$ & $\begin{array}{l}1 \\
(\mathrm{WTS} 700)\end{array}$ & $\begin{array}{l}\text { Air temperature } \\
\text { Air speed } \\
\text { Relative humidity }\end{array}$ & $\begin{array}{l}-40^{\circ} \mathrm{C} \text { to } 60^{\circ} \mathrm{C} \\
0 \text { to } 60 \mathrm{~m} / \mathrm{s} \\
0 \% \text { to } 100 \%\end{array}$ & $\begin{array}{l} \pm 0.3^{\circ} \mathrm{C} \\
\pm 0.3 \mathrm{~m} / \mathrm{s} \\
\pm 2 \%\end{array}$ \\
\hline
\end{tabular}

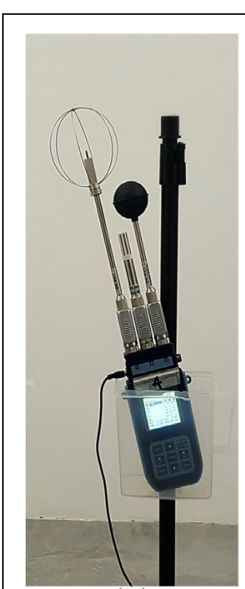

(a)

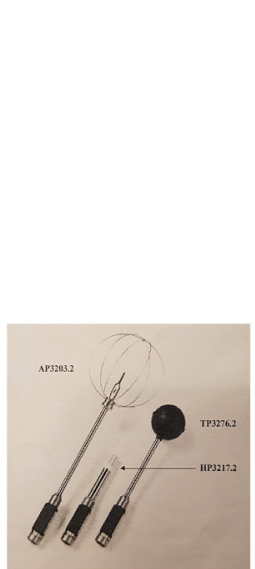

(b)

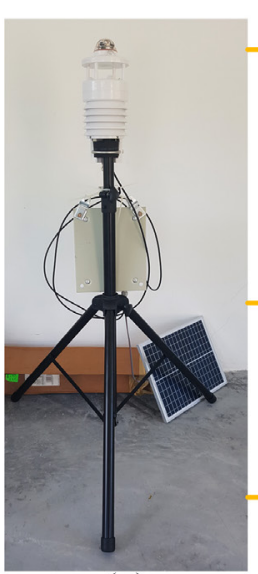

(c)

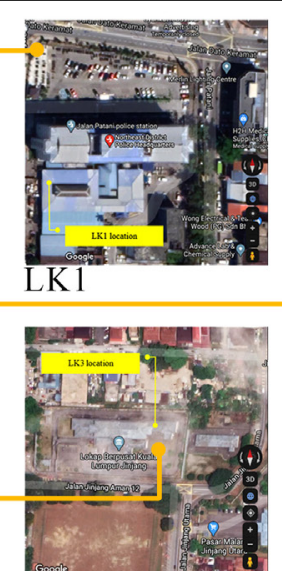

(d)

LK3

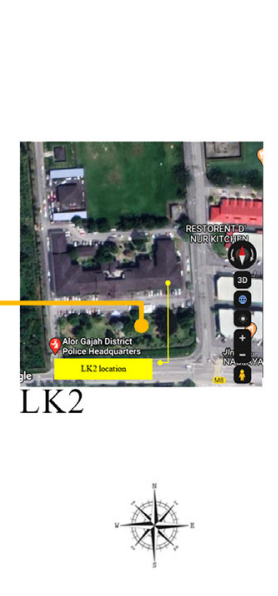

Figure 3. The instruments used in the present study: (a) Delta Ohm Thermocouple Infrared Thermometer; (b) The instruments probe; (c) Seven Elements Integrated Weather Sensor WTS700; (d) Seven Elements Integrated Weather Sensor WTS700 location for all three case study lockups

activities (steady-state conditions). Seven Elements Integrated Weather Sensor WTS700 was located at an open space outside the building with no airflow obstruction.

The evaluation of indoor thermal comfort performance was conducted based on ASHRAE Standard 55 - 'Thermal Environmental Conditions for Human Occupancy' recommendation as shown in Table 7 as it is more relevant for this study and recognized globally (Gharakhani et al., 2014; Xue et al., 2016).

\section{RESULTS AND DISCUSSION}

This section shows the results obtained based on the field study conducted for all three case study lockups. Statistical summaries of the indoor and outdoor measurements, prediction of 
Bismiazan Abd. Razak, Mohd. Farid Mohamed, Wardah Fatimah Mohammad Yusoff and Mohd. Khairul Azhar Mat Sulaiman

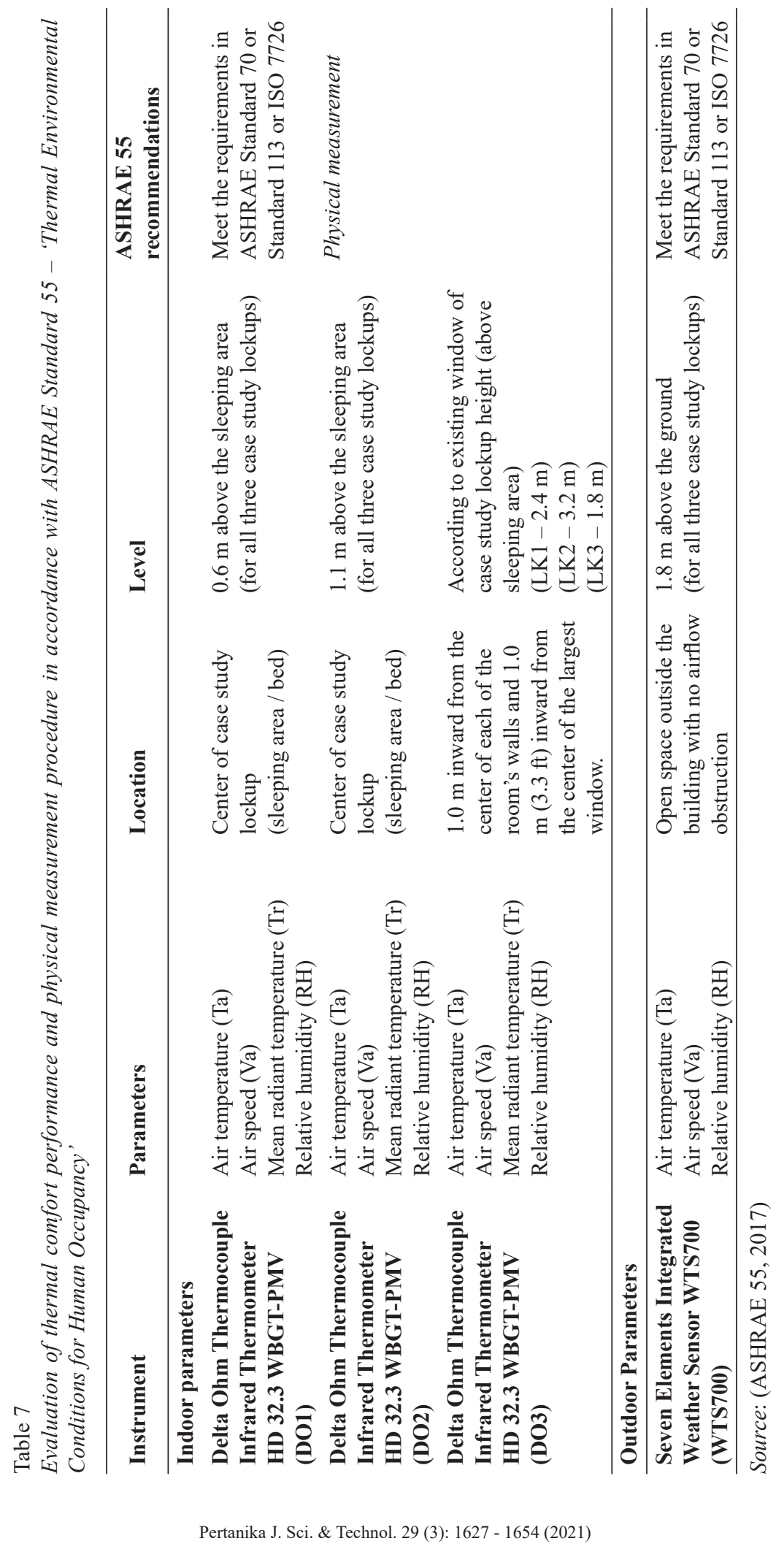


the indoor operative temperature (To) and indoor neutral operative temperature (Tneutop) for LK1, LK2 and LK3 were discussed and compared to ASHRAE 55 using parameters range and recommended comfort criteria.

\section{Statistical Summaries of the Indoor and Outdoor Measurements, Analysis of Prediction of the Indoor Operative Temperature (To) and Indoor Neutral Operative Temperature (Tneutop) for LK1}

Figure 4 shows the statistical summaries of the indoor and outdoor measurements recorded from all three measuring instruments in LK1 for five days measurement.

The average indoor air temperature recorded is higher than ASHRAE 55 which is $31.7^{\circ} \mathrm{C}$ for DO1 and DO3 and $31.4^{\circ} \mathrm{C}$ for DO2. The readings recorded shows small difference from the average outdoor air temperature with average reading $31.0^{\circ} \mathrm{C}$ as shown in Figure 4a.

The average indoor air speed recorded by DO1 and DO2 is equal with reading 0.07 $\mathrm{m} / \mathrm{s}$ for both instruments. However, DO3 shows slightly high average indoor air speed reading which is $0.25 \mathrm{~m} / \mathrm{s}$ as shown in Figure $4 \mathrm{~b}$. The difference in DO3 readings may be influenced by the levelling difference, positioning to the window and window opening. DO3 was levelled slightly higher compared to DO1 and DO2 which at the same time give it a position nearer to the window. The reading collected by the DO3 may highly influenced by high average outdoor air speed $0.77 \mathrm{~m} / \mathrm{s}$ and large window opening $(2.7 \mathrm{~m}(\mathrm{~W}) \times 1.0$ $\mathrm{m}(\mathrm{H}))$ with $30 \%$ of floor area.

The average indoor relative humidity recorded are $60.1 \%$ for DO1, 58.2\% for DO2, and $59.7 \%$ for DO3 as shown in Figure 4c. The average indoor relative humidity recorded are not much different compared to the average outdoor humidity with reading $58.3 \%$. The average indoor relative humidity recorded are good and within the acceptable range by ASHRAE 55. This might be due to the ample mean air speed to facilitate indoor air circulation, which in turn helps in reducing LK1 humidity.

The mean radiant temperature recorded during field measurements are $31.6^{\circ} \mathrm{C}$ for DO1, $31.3^{\circ} \mathrm{C}$ for $\mathrm{DO} 2$ and $31.5^{\circ} \mathrm{C}$ for $\mathrm{DO} 3$ as shown in Figure $4 \mathrm{~d}$. It shows not much difference between the three readings recorded. The mean radiant temperature readings are slightly lower than the result of mean air temperature readings. This indicates that there are other influencing factors.

Indoor and outdoor measurement data obtained were then used to predict operative temperature and neutral operative temperature. In the present study, linear regression by using Equation 1 was selected in calculating operative temperature because it is widely used method for neutral temperature prediction according to ASHRAE 55.

According to Equation 1, the value of A used in the calculation of operative temperature for DO1 and DO2 is 0.5 because the average air speed $<0.2 \mathrm{~m} / \mathrm{s}$ while for DO3, the value 


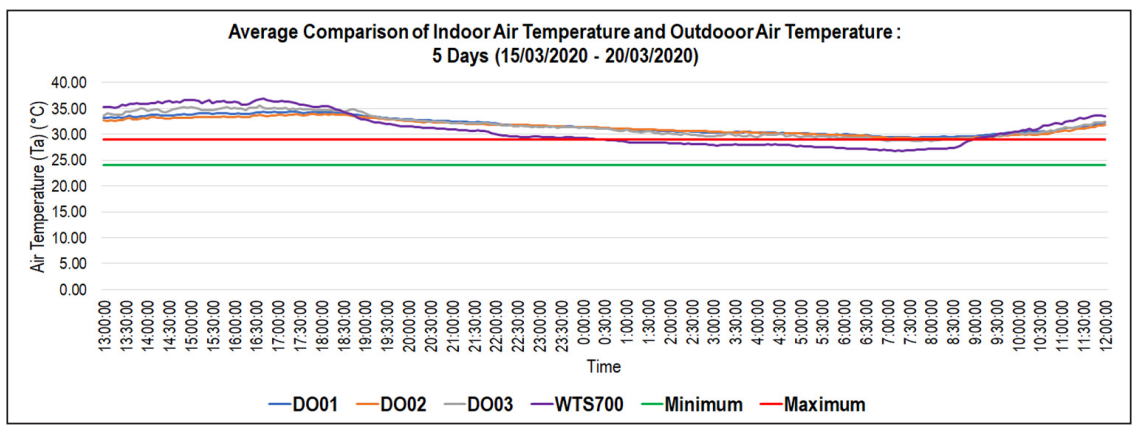

(a)

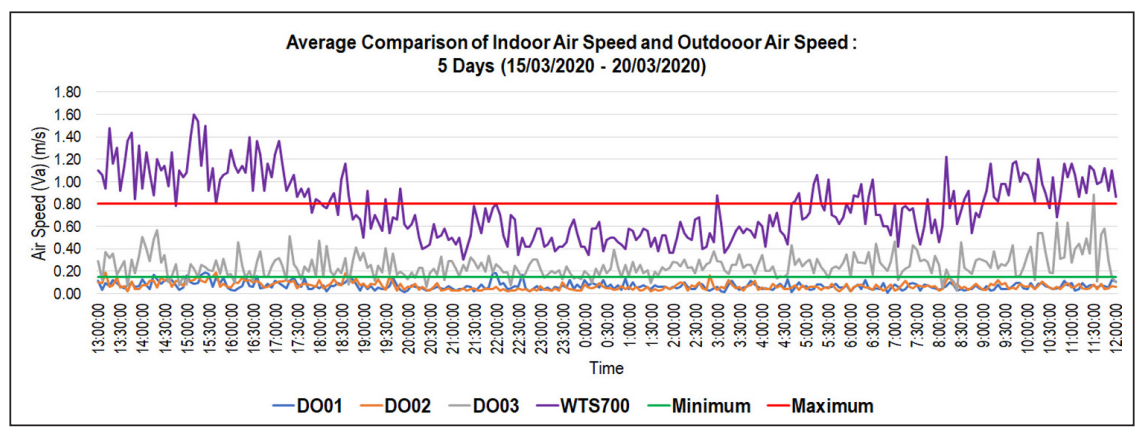

(b)

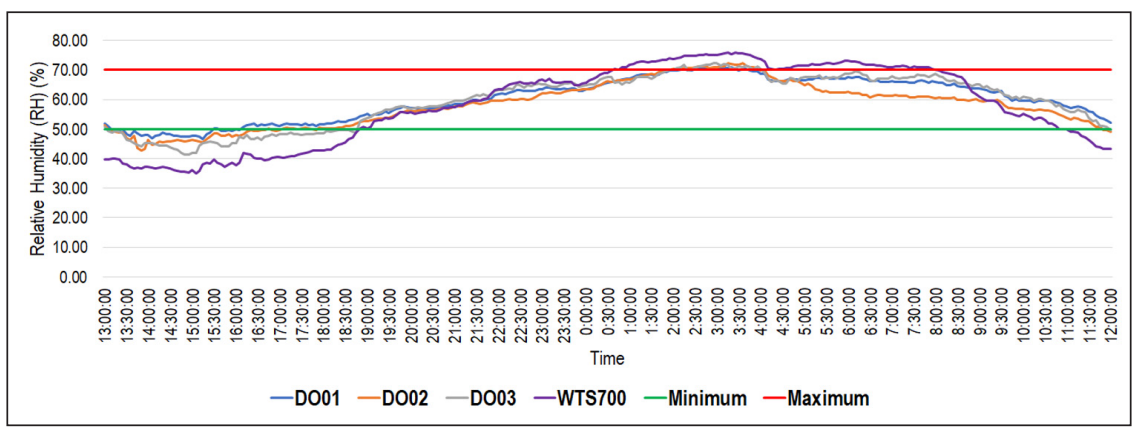

(c)

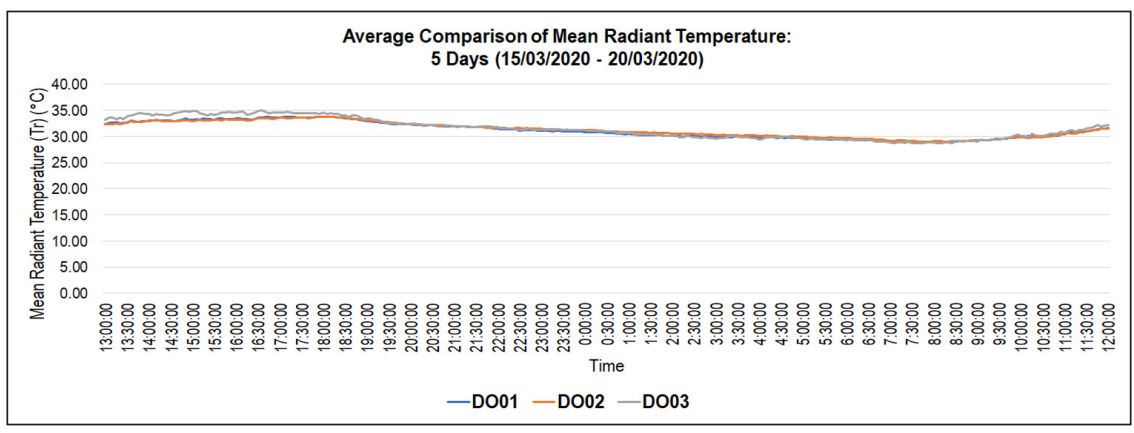

(d)

Figure 4. Statistical summaries of the average comparison indoor and outdoor measurements for LK1: (a) Air temperature; (b) Air speed; (c) Relative humidity; (d) Mean radiant temperature 
of A used is 0.6 because the average air speed recorded is $0.25 \mathrm{~m} / \mathrm{s}$ which is in $0.2 \mathrm{~m} / \mathrm{s}$ to $0.6 \mathrm{~m} / \mathrm{s}$ range.

The Tneutop determined by Equation 2 was used in calculating neutral operative temperature. To use this equation, daily average outdoor air temperature (Toutdm) must be in the range between $19.4^{\circ} \mathrm{C}$ to $30.5^{\circ} \mathrm{C}$ and indoor air speed $<0.65 \mathrm{~m} / \mathrm{s}$ at and below neutral operative temperature; $\geq 0.65$ above neutral operative temperature. There is no limit for indoor humidity set in this equation. Average indoor air speed for LK1 is within the set limit which is $<0.65 \mathrm{~m} / \mathrm{s}$ while daily average outdoor air temperature for LK1 slightly exceed the set limit by the equation about $+0.05^{\circ} \mathrm{C}$ during calculation.

As a result, the indoor operative temperature is between $31.4^{\circ} \mathrm{C}$ to $31.6^{\circ} \mathrm{C}$ while the neutral operative temperature is $31.5^{\circ} \mathrm{C}$ for LK1 as shown in Figure 5.

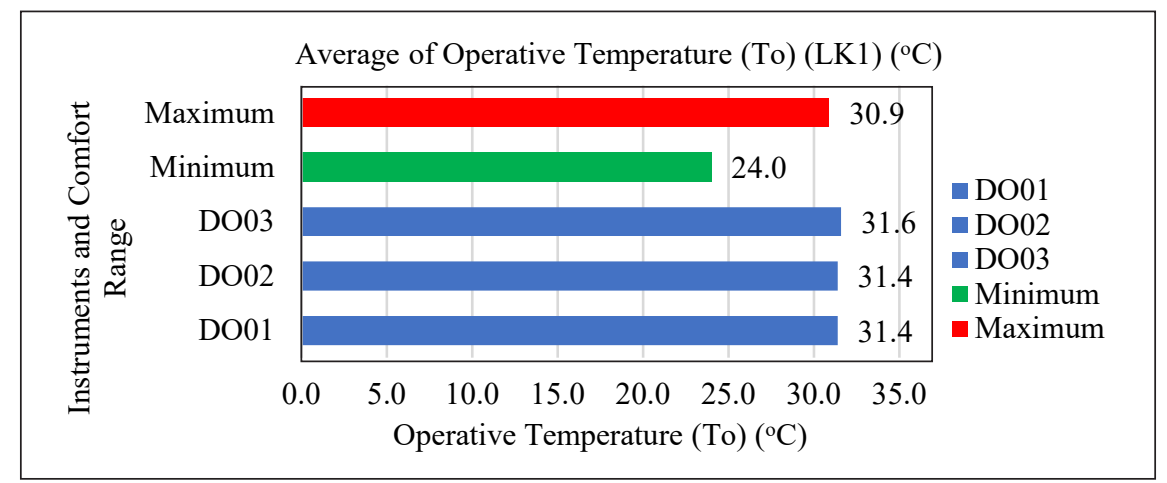

(a)

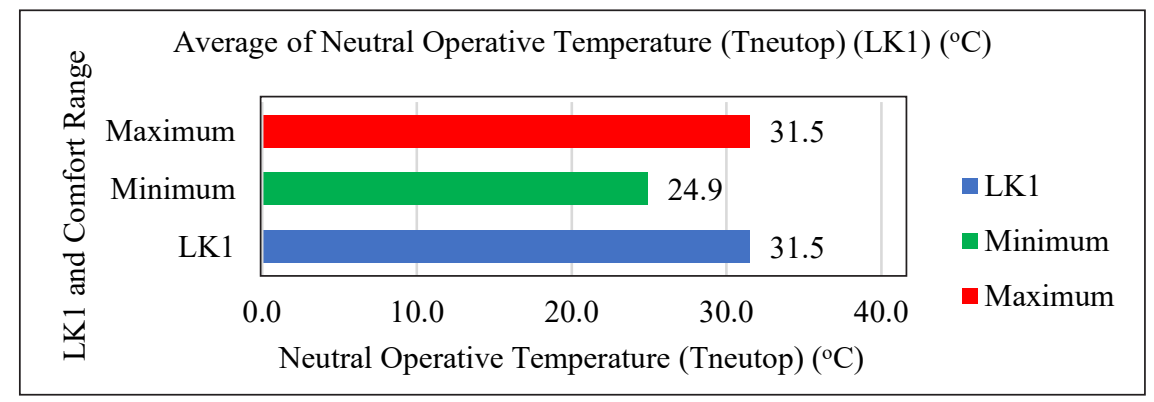

(b)

Figure 5. Summaries of the (a) operative temperature and (b) neutral operative temperature prediction for LK1

\section{Statistical Summaries of the Indoor and Outdoor Measurements, Analysis of Prediction of the Indoor Operative Temperature (To) and Indoor Neutral Operative Temperature (Tneutop) for LK2}

Figure 6 shows the statistical summaries of the indoor and outdoor measurements recorded from all three measuring instruments in LK2 for five days measurement. 


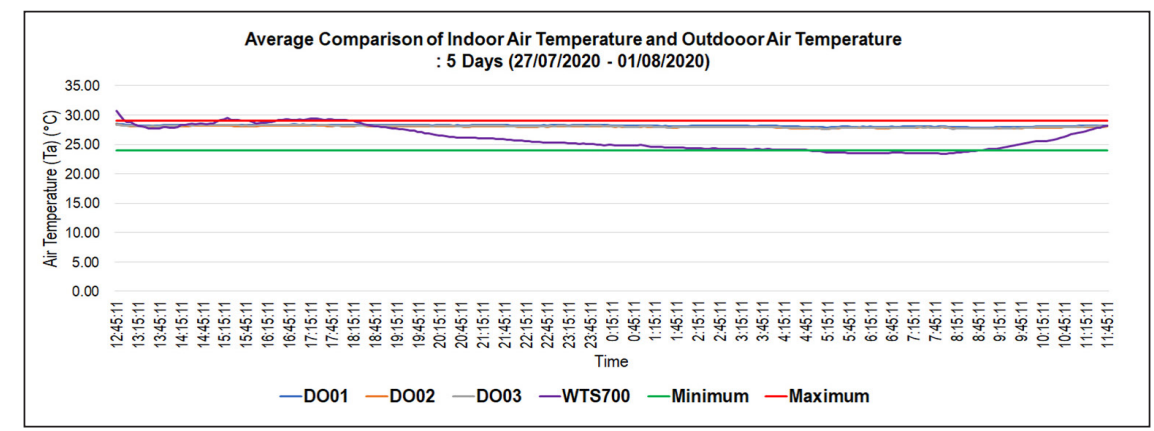

(a)

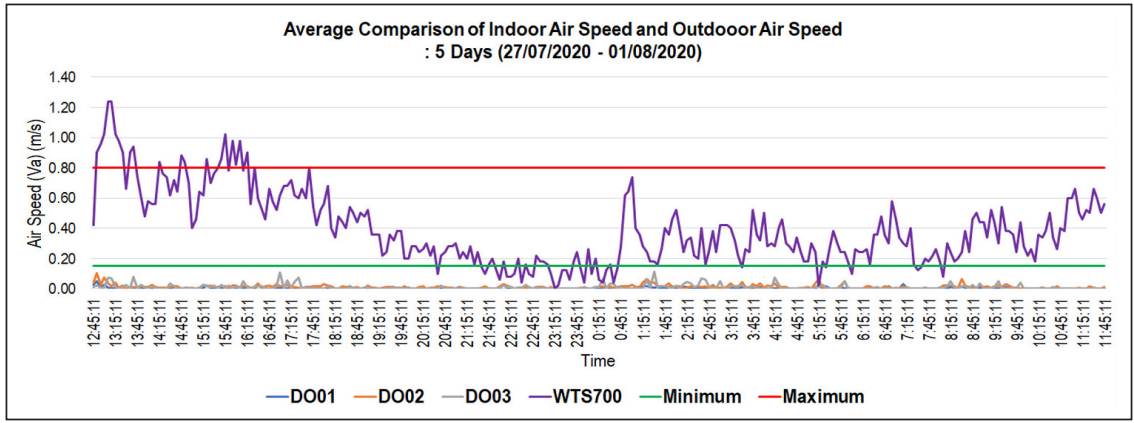

(b)

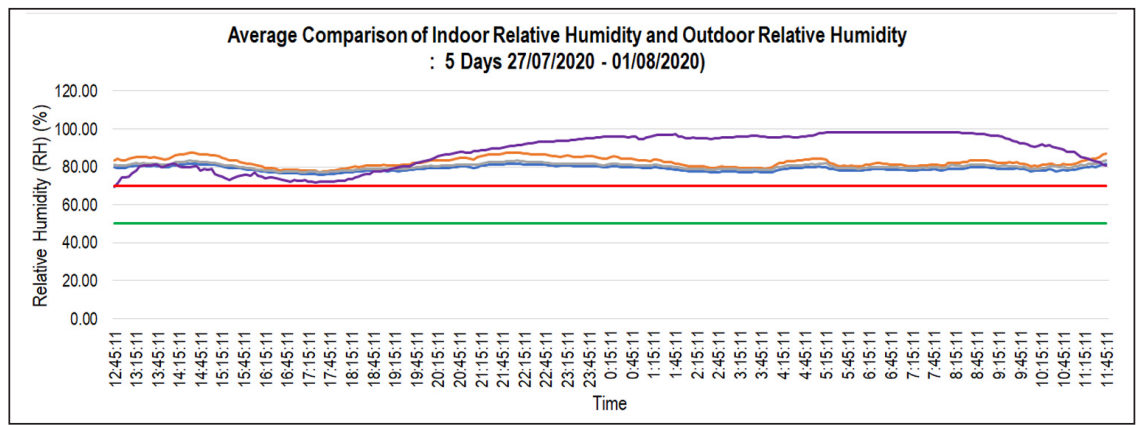

(c)

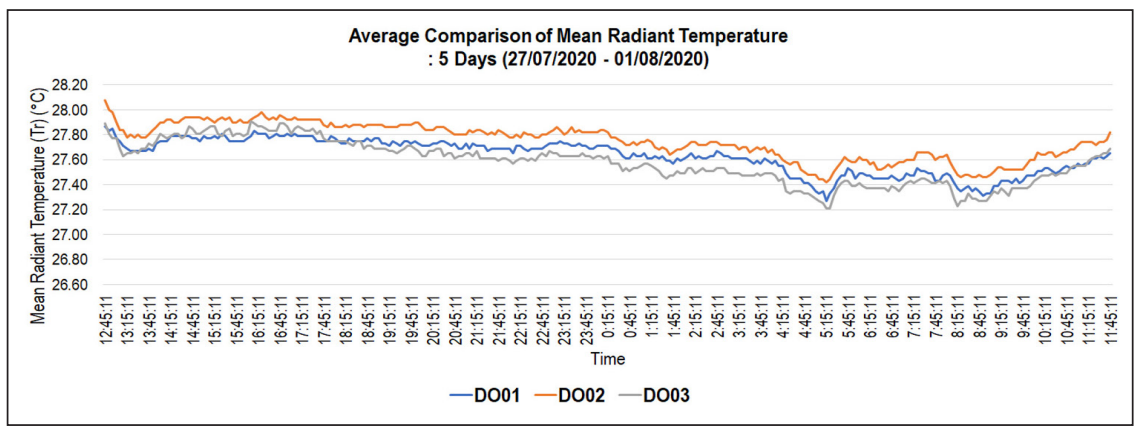

(d)

Figure 6. Statistical summaries of the average comparison indoor and outdoor measurements for LK2: (a) Air temperature; (b) Air speed; (c) Relative humidity; (d) Mean radiant temperature 
The average indoor air temperature recorded are $28.2^{\circ} \mathrm{C}$ for $\mathrm{DO} 1,28.0^{\circ} \mathrm{C}$ for $\mathrm{DO} 2$, and $28.1^{\circ} \mathrm{C}$ for DO3. The readings recorded are slightly higher than the average outdoor air temperature with readings $26.0^{\circ} \mathrm{C}$ as shown in Figure 6a.

The average indoor air speed recorded by DO1, DO2 and DO3 is too low and not much different compared to each other with readings between $0.00 \mathrm{~m} / \mathrm{s}$ to $0.01 \mathrm{~m} / \mathrm{s}$ although the DO3 was positioned near to the window as shown in Figure $6 \mathrm{~b}$. This may cause by small window opening $(0.6 \mathrm{~m}(\mathrm{~W}) \times 0.6 \mathrm{~m}(\mathrm{H}))$ with $4 \%$ of floor area which is below $10 \%$ plus $5 \%$ unobstructed opening as required by Malaysian UBBL even though average outdoor air speed recorded is $0.39 \mathrm{~m} / \mathrm{s}$.

The average indoor relative humidity recorded are $79.0 \%$ for DO1, $82.6 \%$ for DO2, and $80.3 \%$ for DO3 as shown in Figure $6 \mathrm{c}$. Average indoor relative humidity recorded are very high and exceed the acceptable range by ASHRAE 55. This may be due to the insufficient mean air speed to facilitate indoor air circulation, which does not help in reducing LK2 humidity and influenced by high outdoor humidity with average $88.5 \%$.

The average mean radiant temperature recorded during field measurements are $27.6^{\circ} \mathrm{C}$ for $\mathrm{DO} 1,27.8^{\circ} \mathrm{C}$ for $\mathrm{DO} 2$, and $27.6^{\circ} \mathrm{C}$ for $\mathrm{DO} 3$ and there is not much difference between the three readings recorded as shown in Figure $6 \mathrm{~d}$. The average mean radiant temperature readings are slightly lower than the result of average indoor air temperature readings and

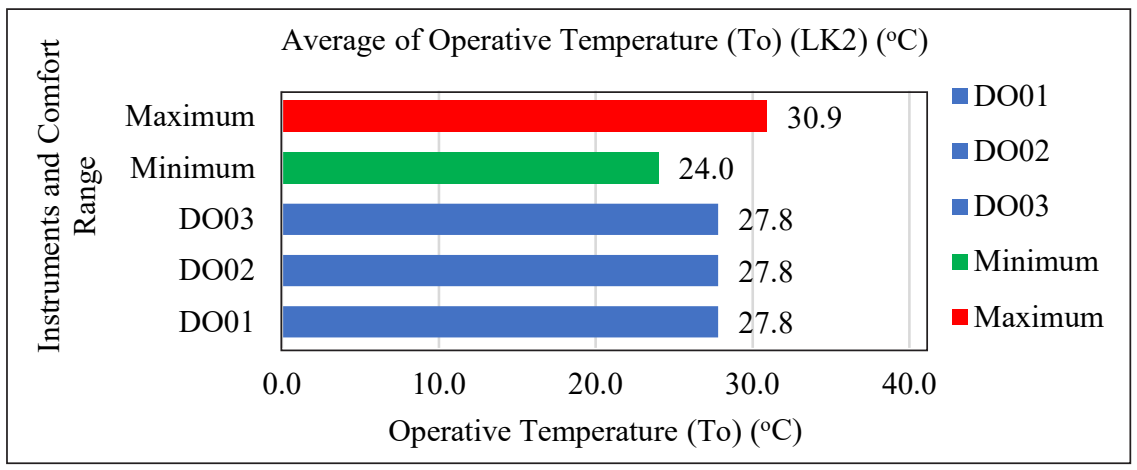

(a)

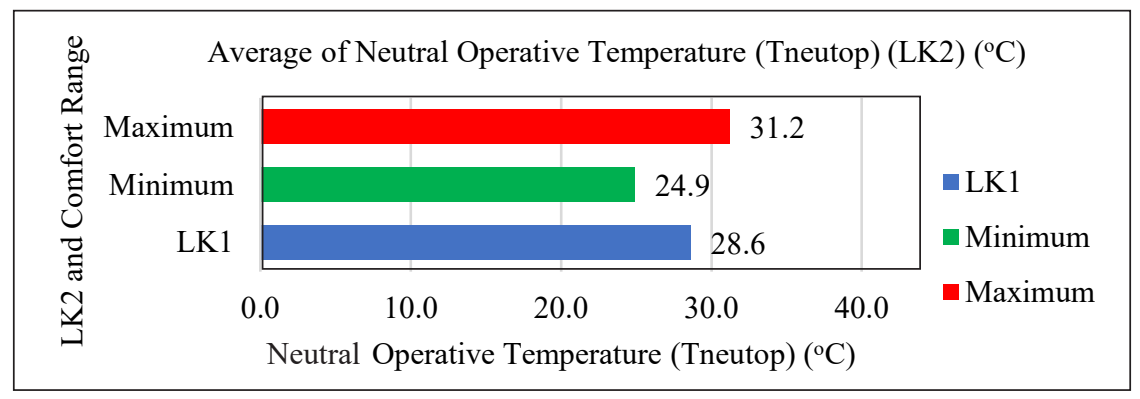

(b)

Figure 7. Summaries of the (a) operative temperature and (b) neutral operative temperature prediction for LK2 
this indicates that there are other influencing factors such as space height where LK2 in slightly higher with $3.2 \mathrm{~m}$ height.

According to Equation 1, the value of A used in the calculation of operative temperature for all measurement instruments (DO1, DO2 and DO3) is 0.5 because the average air speed $<0.2 \mathrm{~m} / \mathrm{s}$ which is between $0.00 \mathrm{~m} / \mathrm{s}$ to $0.01 \mathrm{~m} / \mathrm{s}$ only.

The average indoor air speed which is between $0.00 \mathrm{~m} / \mathrm{s}$ to $0.01 \mathrm{~m} / \mathrm{s}$ and average outdoor air temperature which is between $26.0^{\circ} \mathrm{C}$ for LK2 is within the set limit and comply with the requirements as prescribed by Equation 2.

The indoor operative temperature has been determined between $27.8^{\circ} \mathrm{C}$ to $27.9^{\circ} \mathrm{C}$ while the neutral operative temperature is $28.6^{\circ} \mathrm{C}$ for LK2 as shown in Figure 7.

\section{Statistical Summaries of the Indoor and Outdoor Measurements, Analysis of Prediction of the Indoor Operative Temperature (To) and Indoor Neutral Operative Temperature (Tneutop) for LK3}

Figure 8 shows the statistical summaries of the indoor and outdoor measurements recorded from all three measuring instruments in LK3 for five days measurement.

The average indoor air temperature recorded are $28.7^{\circ} \mathrm{C}$ for DO1 and DO3 and $28.5^{\circ} \mathrm{C}$ for DO2. The readings recorded are slightly higher than the average outdoor air temperature with reading $27.3^{\circ} \mathrm{C}$ as shown in Figure 8a.

The average indoor air speed recorded by DO1, DO2 and DO3 is also low and not much different with readings between $0.01 \mathrm{~m} / \mathrm{s}$ to $0.04 \mathrm{~m} / \mathrm{s}$ although DO3 was positioned near to the window opening as shown in Figure $8 \mathrm{~b}$. The low LK3 reading might be influenced by small window opening $(0.6 \mathrm{~m}(\mathrm{~W}) \times 0.6 \mathrm{~m}(\mathrm{H}))$ with $4.6 \%$ of floor area which is below $10 \%$ plus $5 \%$ unobstructed opening as required by Malaysian UBBL even though average outdoor air speed recorded is quite high which is between $0.32 \mathrm{~m} / \mathrm{s}$ to $0.53 \mathrm{~m} / \mathrm{s}$. In addition, the average air speed recorded is higher about +0.01 to $+0.03 \mathrm{~m} / \mathrm{s}$ than recorded by LK2.

The average indoor relative humidity recorded are $77.5 \%$ for DO1, $80.6 \%$ for DO2 and $78.8 \%$ for DO3 as shown in Figure $8 \mathrm{c}$. Average indoor relative humidity recorded are very high and exceed the acceptable range by ASHRAE 55. This may be due to the low average air speed in facilitating indoor air circulation, which does not help in reducing LK3 humidity. It may also influence by high average outdoor humidity with reading of $81.9 \%$.

The average mean radiant temperature recorded during field measurements are $28.2^{\circ} \mathrm{C}$ for DO1, $28.3^{\circ} \mathrm{C}$ for DO2 and $28.4^{\circ} \mathrm{C}$ for DO3. There is not much difference between the three readings recorded as shown in Figure 8d. The mean radiant temperature is slightly lower than mean air temperature. This indicates other influencing factors such as the effect of epoxy paint finish on the LK3 walls which is still in a good condition during the measurement period. 
Thermal Comfort Performance of Royal Malaysian Police (RMP) Lockup

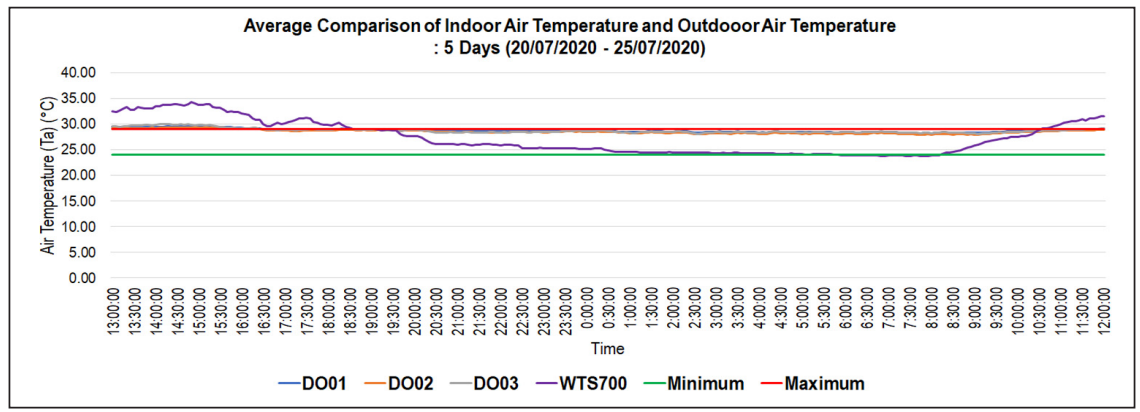

(a)

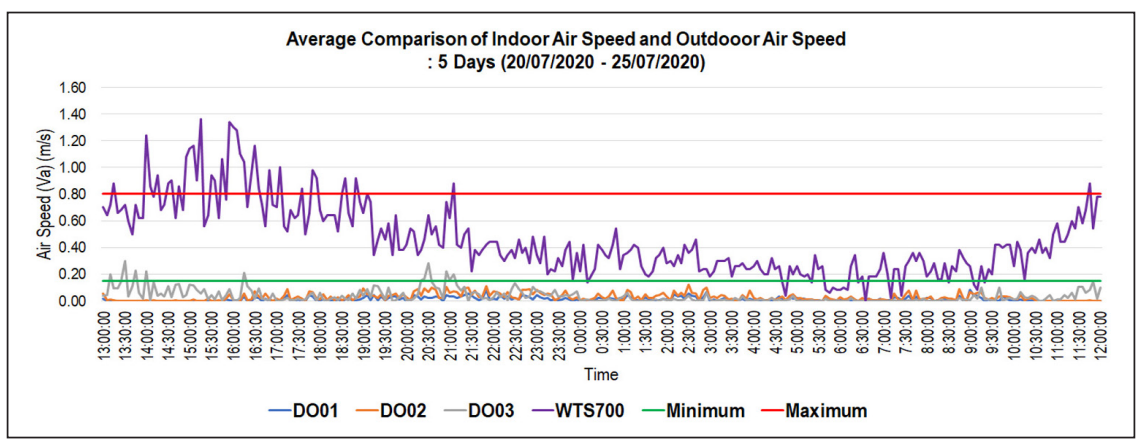

(b)

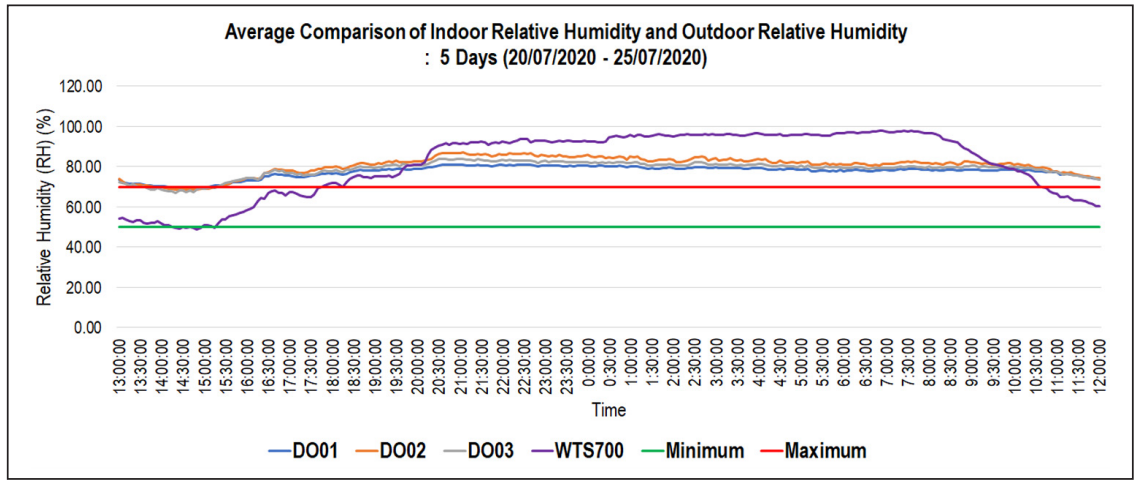

(c)

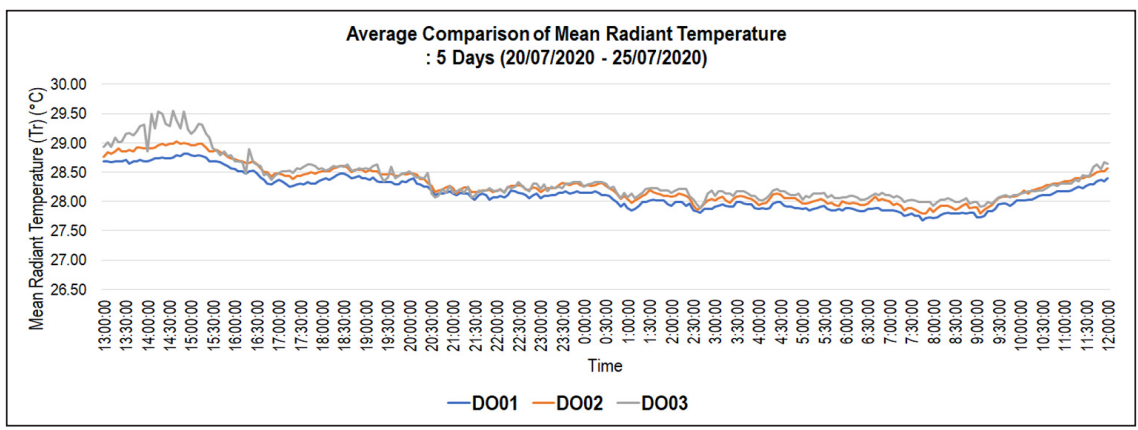

(d)

Figure 8. Statistical summaries of the average comparison indoor and outdoor measurements for LK3: (a) Air temperature; (b) Air speed; (c) Relative humidity; (d) Mean radiant temperature 


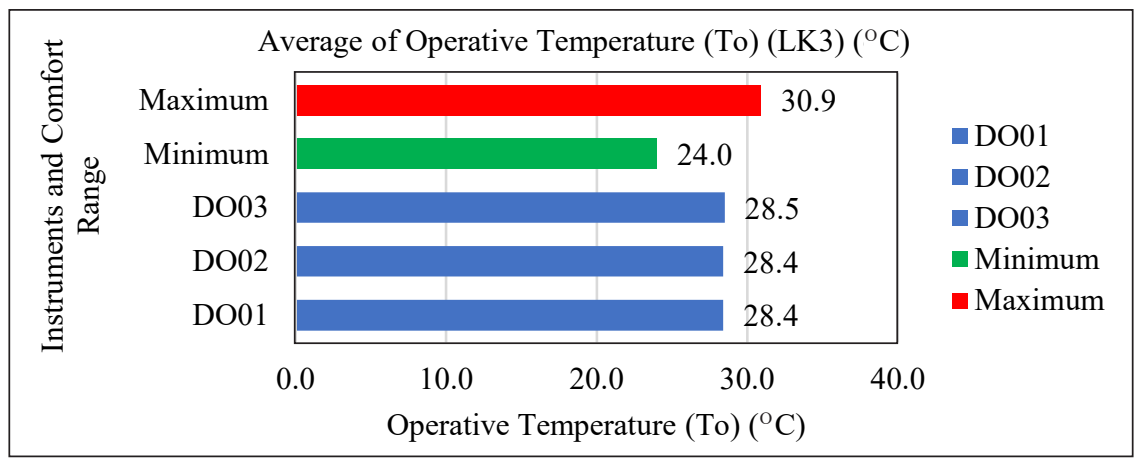

(a)

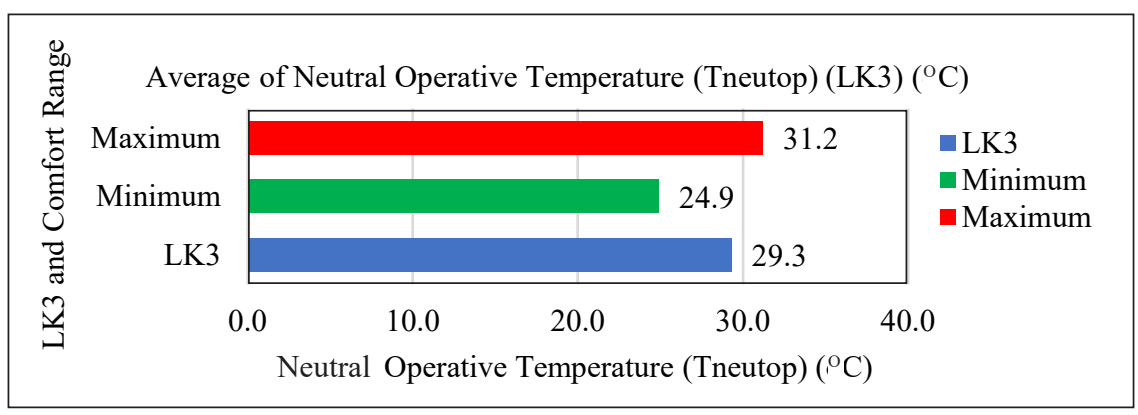

(b)

Figure 9. Summaries of the operative temperature and neutral operative temperature prediction for LK3

According to Equation 1, the value of A used in the calculation of operative temperature for all LK3 measurement instruments (DO1, DO2 and DO3) is 0.5 because the average air speed $<0.2 \mathrm{~m} / \mathrm{s}$ which is between $0.01 \mathrm{~m} / \mathrm{s}$ to $0.04 \mathrm{~m} / \mathrm{s}$ only.

The average indoor air speed which is between $0.01 \mathrm{~m} / \mathrm{s}$ to $0.04 \mathrm{~m} / \mathrm{s}$ and average outdoor air temperature $27.3^{\circ} \mathrm{C}$ for LK3 is also within the set limit which is between $19.4^{\circ} \mathrm{C}$ to $30.5^{\circ} \mathrm{C}$ and comply with the requirements as prescribed by Equation 2 .

The indoor operative temperature has been determined between $28.4^{\circ} \mathrm{C}$ to $28.5^{\circ} \mathrm{C}$ while the neutral operative temperature is $29.3^{\circ} \mathrm{C}$ for LK3 as shown in Figure 9.

\section{Discussions and Comparison to ASHRAE 55 and Previous Studies}

To evaluate thermal comfort performance, comfort range for thermal comfort recommended by ASHRAE 55 (2017) (minimum range), Zain et al. (2007) (maximum range) and Toe \& Kubota (2013) for naturally ventilated building in hot and humid climate were used as shown in Table 8.

The average indoor operative temperature obtained in the present study for LK1 $\left(31.4^{\circ} \mathrm{C}\right.$ to $31.6^{\circ} \mathrm{C}$ ) is slightly exceeding the maximum limit recommended by ASHRAE 55 (2017) by about $+2.4^{\circ} \mathrm{C}$ to $+2.6^{\circ} \mathrm{C}$ and Zain et al. (2007) by about $+0.5^{\circ} \mathrm{C}$ to $+0.7^{\circ} \mathrm{C}$. The average neutral operative temperature obtained in the present study for LK1 $\left(31.5^{\circ} \mathrm{C}\right)$ is also found 
Table 8

Comparison of comfort range and recommended comfort criteria among previous studies, ASHRAE 55 and present study

\begin{tabular}{|c|c|c|c|c|}
\hline Parameters & $\begin{array}{l}\text { (ASHRAE 55, } \\
\text { 2017) } \\
\text { (minimum } \\
\text { range) }\end{array}$ & $\begin{array}{l}\text { (Zain et al., } \\
\text { 2007) } \\
\text { (maximum } \\
\text { range) }\end{array}$ & $\begin{array}{c}\text { (Toe \& Kubota, 2013) } \\
\text { (minimum to } \\
\text { maximum range) }\end{array}$ & $\begin{array}{l}\text { Present study } \\
\text { (average) }\end{array}$ \\
\hline $\begin{array}{l}\text { Operative } \\
\text { temperature }\end{array}$ & $24.0^{\circ} \mathrm{C}-29.0^{\circ} \mathrm{C}$ & $30.9^{\circ} \mathrm{C}$ & NA & $\begin{array}{l}\text { LK1: } 31.4^{\circ} \mathrm{C} \text { to } 31.6^{\circ} \mathrm{C} \\
\text { LK2: } 27.8^{\circ} \mathrm{C} \text { to } 27.9^{\circ} \mathrm{C} \\
\text { LK3: } 28.4^{\circ} \mathrm{C} \text { to } 28.5^{\circ} \mathrm{C}\end{array}$ \\
\hline $\begin{array}{l}\text { Neutral } \\
\text { operative } \\
\text { temperature }\end{array}$ & NA & NA & $24.9-31.2^{\circ} \mathrm{C}$ & $\begin{array}{l}\text { LK1: } 31.5^{\circ} \mathrm{C} \\
\text { LK2: } 28.6^{\circ} \mathrm{C} \\
\text { LK3: } 29.3^{\circ} \mathrm{C}\end{array}$ \\
\hline
\end{tabular}

slightly exceeding the maximum limit by about $+0.3{ }^{\circ} \mathrm{C}$ compared to the indoor comfort temperature recommended by Toe \& Kubota (2013).

The average indoor operative temperature obtained in the present study for LK2 $\left(27.8^{\circ} \mathrm{C}\right.$ to $\left.27.9^{\circ} \mathrm{C}\right)$ and $\operatorname{LK} 3\left(28.4^{\circ} \mathrm{C}\right.$ to $\left.28.5^{\circ} \mathrm{C}\right)$ recorded within the minimum and maximum limit as recommended by ASHRAE 55 (2017) and Zain et al. (2007). The average neutral operative temperature obtained in the present study for LK2 $\left(28.6^{\circ} \mathrm{C}\right)$ and LK3 $\left(29.3{ }^{\circ} \mathrm{C}\right)$ recorded within the indoor comfort temperature recommended by Toe \& Kubota (2013).

\section{CONCLUSION}

Field study with physical measurement of the thermal environment and comfort in three different lockups were in hot and humid climate conducted to investigate and analysis the thermal comfort performance and to predict comfort range for all three case study lockups. Although 3 sets of measurement instruments were used in the present study, the reading data obtained between the three instruments were not much different from each other. The conclusions are as follows:

1. LK1 - Average indoor air temperature reading is high which may be due to large window opening. Based on the field measurement, the window opening is $30 \%$ of the floor area which $15 \%$ exceeding Malaysian UBBL requirement. Other influencing factors are high average outdoor air speed and wind direction which is perpendicular to window opening. Since the field study were conducted during hot season, the air brought into the lockup was hot and dry which cause low relative humidity. The operative temperature obtained is slightly exceeding the maximum range recommended by ASHRAE 55 (2017) by about $+2.4^{\circ} \mathrm{C}$ to $+2.6^{\circ} \mathrm{C}$ and Zain et al. (2007) by about $+0.4^{\circ} \mathrm{C}$ to $+0.7^{\circ} \mathrm{C}$. The neutral operative temperature obtained in the present study for LK1 $\left(31.5^{\circ} \mathrm{C}\right)$ also found slightly exceeding by about $+0.3^{\circ} \mathrm{C}$ within the recommended by Toe \& Kubota (2013). 
2. LK2 - Average indoor air temperature reading is within the range recommended by ASHRAE 55 (2017). While indoor relative humidity reading is high which may be due to insufficient indoor air speed which caused by small window opening, $4 \%$ of the floor area which $11 \%$ below Malaysian UBBL requirement although wind direction is perpendicular with the window opening. The indoor operative temperature obtained is within the minimum and maximum range recommended by ASHRAE 55 (2017) and Zain et al. (2007) while indoor neutral operative temperature for LK2 $\left(28.6^{\circ} \mathrm{C}\right)$ recorded within the recommended by Toe \& Kubota (2013).

3. LK3 - Average indoor air temperature reading is within the range recommended by ASHRAE 55 (2017). While indoor relative humidity reading is high which may be due to insufficient indoor air speed which caused by small window opening, $4.6 \%$ of the floor area which is $10.4 \%$ below Malaysian UBBL requirement and parallel wind direction to the window opening. The indoor operative temperature obtained is within the minimum and maximum range recommended by ASHRAE 55 (2017) and Zain et al. (2007) while indoor neutral operative temperature for LK2 $\left(29.3^{\circ} \mathrm{C}\right)$ recorded within the recommended by Toe \& Kubota (2013).

4. In general, this three case study lockups have different window openings and space volume which influence indoor thermal comfort performance. Thus, subsequent study shall look on this aspect to determinant its level of influence.

5. The results of the three case study lockups support most of the statements made by the detainees as stated in NGO's report and previous studies which is the lockup is hot and contribute to discomfort among detainees as mentioned earlier.

This is an early study for future rigorous investigation that will lead to better understanding on the effect of opening design on the thermal comfort performance of lockup. In addition, further study using static models of thermal comfort through the Predicted Mean Vote (PMV) and Percentage of People Dissatisfied (PPD) indexes on existing detainees are recommended to be conducted to compliment the results obtained in this study in producing comprehensive results on the thermal comfort performance of RMP lockups.

\section{ACKNOWLEDGEMENT}

The authors would like to take this opportunity to express their gratitude to the National University of Malaysia (UKM) for the support and assistance that was channeled through the Fundamental Research Grant Scheme (FRGS/1/2020/TK0/UKM/02/26) and Dana Cabaran Perdana (DCP-2017-008/5). A sincere appreciation also goes to the Architecture Branch of the Public Works Department (PWD/JKR) Malaysia and the Royal Malaysia Police (RPM). 


\section{REFERENCES}

Al-Absi, Z. A., \& Abas, N. F. (2018). Subjective assessment of thermal comfort for residents in naturally ventilated residential building in Malaysia. In IOP Conference Series: Materials Science and Engineering (Vol. 401, p. 012009). IOP Publishing. https://doi.org/10.1088/1757-899X/401/1/012009

Aminuddin, A. M. R., Rao, S. P., \& Hong, W. T. (2012). Thermal comfort field studies in two certified energy efficient office buildings in a tropical climate. International Journal of Sustainable Building Technology and Urban Development, 3(2), 129-136. https://doi.org/10.1080/2093761X.2012.696324

ASHRAE 55. (2017). ASHRAE 55-2017 - Thermal Environmental Conditions for Human Occupancy. Retrieved June 6, 2020, from www.ashrae.org

Attia, S., \& Carlucci, S. (2015). Impact of different thermal comfort models on zero energy residential buildings in hot climate. Energy and Buildings, 102, 117-128. https://doi.org/10.1016/j.enbuild.2015.05.017

Azizpour, F., Moghimi, S., Lim, C. H., Mat, S., Salleh, E., \& Sopian, K. (2013). A thermal comfort investigation of a facility department of a hospital in hot-humid climate: Correlation between objective and subjective measurements. Indoor and Built Environment, 22(5), 836-845. https://doi.org/10.1177/1420326X12460067

Azizpour, F., Moghimi, S., Mat, S., Lim, C., \& Sopian, K. (2011). Objective and subjective assessment of thermal comfort in hot-humid region. In Proceedings of 5th WSEAS international conferences on Recent Researches in Chemistry, Biology, Environment and Culture (pp. 207-210). WSEAS Press.

Chan, S. C., Che-Ani, A. I., \& Ibrahim, N. L. N. (2013). Passive designs in sustaining natural ventilation in school office buildings in Seremban, Malaysia. International Journal of Sustainable Built Environment, 2(2), 172-182. https://doi.org/10.1016/j.ijsbe.2014.01.002

Dahlan, N. D., Jones, P. J., Alexander, D. K., Salleh, E., \& Dixon, D. (2008). Field measurement and subjects' votes assessment on thermal comfort in high-rise hostels in Malaysia. Indoor and Built Environment, 17(4), 334-345. https://doi.org/10.1177/1420326X08094585

Damiati, S. A., Zaki, S. A., Rijal, H. B., \& Wonorahardjo, S. (2016). Field study on adaptive thermal comfort in office buildings in Malaysia, Indonesia, Singapore, and Japan during hot and humid season. Building and Environment, 109, 208-223. https://doi.org/10.1016/j.buildenv.2016.09.024

Davies, N., \& Jokiniemi, E. (2008). Dictionary of architecture and building construction. Routledge. https:// doi.org/10.4324/9780080878744

de Dear, R. J., \& Brager, G. S. (2002). Thermal comfort in naturally ventilated buildings: Revisions to ASHRAE standard 55. Energy and Buildings, 34, 549-561. https://doi.org/10.1016/S0378-7788(02)00005-1

Djamila, H., Chu, C. M., \& Kumaresan, S. (2013). Field study of thermal comfort in residential buildings in the equatorial hot-humid climate of Malaysia. Building and Environment, 62, 133-142. https://doi. org/10.1016/j.buildenv.2013.01.017

Dogbeh, A., Jomaas, G., Bjarløv, S. P., \& Toftum, J. (2014). Field study of the indoor environment in a Danish Prison. Building and Environment, 88, 20-26. https://doi.org/10.1016/j.buildenv.2014.10.025

Fabbri, K. (2013). Thermal comfort evaluation in kindergarten: PMV and PPD measurement through datalogger and questionnaire. Building and Environment, 68, 202-214. https://doi.org/10.1016/j.buildenv.2013.07.002 
Feriadi, H., \& Wong, N. H. (2004). Thermal comfort for naturally ventilated houses in Indonesia. Energy and Buildings, 36, 614-626. https://doi.org/10.1016/j.enbuild.2004.01.011

Gharakhani, A., Sediadi, E., Khan, T. H., \& Sabzevar, H. B. (2014). Use of natural ventilation in Malaysia's future green housing. Advanced Materials Research, 935, 316-319. https://doi.org/10.4028/www.scientific. net/AMR.935.316

Han, J., Zhang, G., Zhang, Q., Zhang, J., Liu, J., Tian, L., Zheng, C., Hao, J., Lin, J., Liu, Y., \& Moschandreas, D. J. (2007). Field study on occupants' thermal comfort and residential thermal environment in a hot-humid climate of China. Building and Environment, 42, 4043-4050. https://doi.org/10.1016/j. buildenv.2006.06.028

Jabatan Meteorologi Malaysia. (2020). Iklim Malaysia [Malaysia Climate]. Retrieved May 16, 2020, from http://www.met.gov.my/pendidikan/iklim/iklimmalaysia

Jiang, Y., Alexander, D., Jenkins, H., Arthur, R., \& Chen, Q. (2003). Natural ventilation in buildings: Measurement in a wind tunnel and numerical simulation with large-eddy simulation. Journal of Wind Engineering and Industrial Aerodynamics, 91(3), 331-353. https://doi.org/10.1016/S0167-6105(02)00380-X

Kamaruzzaman, K., \& Tazilan, A. S. M. (2013). Thermal comfort assessment of a classroom in tropical climate conditions. Recent Advances in Energy, Environment and Development, 87-91.

Kubota, T., Chyee, D. T. H., \& Ahmad, S. (2009). The effects of night ventilation technique on indoor thermal environment for residential buildings in hot-humid climate of Malaysia. Energy and Buildings, 41, 829839. https://doi.org/10.1016/j.enbuild.2009.03.008

López-Pérez, L. A., Flores-Prieto, J. J., \& Ríos-Rojas, C. (2019). Adaptive thermal comfort model for educational buildings in a hot-humid climate. Building and Environment, 150, 181-194. https://doi. org/10.1016/j.buildenv.2018.12.011

Maarof, S. (2014). Roof designs and affecting thermal comfort factors in a typical naturally ventilated Malaysian mosque (Doctoral dissertation). Cardiff University.

Nordin, R. M., Halim, A. H. A., \& Yunus, J. (2017). Challenges in the implementation of green home development in Malaysia: Perspective of developers. IOP Conference Series: Materials Science and Engineering, 291, 012-020. https://doi.org/10.1088/1757-899X/291/1/012020

Nur'aini, R. D. (2017). Thermal performance simulation of residential building in tropical climate case study: Housing in Bandar Universiti, Malaysia. International Journal of Built Environment and Scientific Research, 1(1), 47-52. https://doi.org/10.24853/ijbesr.1.01.47-52

PDRM. (1953). Peraturan-peraturan lokap 1953 [Lockup rules 1953]. Retrieved November 2, 2020, from https://www.malaysianbar.org.my/document/com_docman/gid/itemid\&rid=9641

Perlembagaan Persekutuan Malaysia. (2010). Perlembagaan Persekutuan Malaysia (Jabatan Peguam Negara (ed.); 160A ed., Vol. 6, Issue 1) [Federal Constitution of Malaysia (Attorney General Chambers of Malaysia (ed.); 160A ed., Vol. 6, Issue 1)]. Pesuruhjaya Penyemak Undang-Undang Malaysia. Retrieved October 21, 2019, from http://www.kptg.gov.my/images/pdf/perundangan-tanah/perlembagaanpersekutuan.pdf 
Razak, B. A., Mohamed, M. F., Yusoff, W. F. M., \& Sulaiman, M. K. A. M. (2020). Research on the design typology of the Royal Malaysian Police (RMP) lockups. International Journal of Advanced Science and Technology, 29(9s), 1866-1884.

SUHAKAM. (2016). Kematian dalam tahanan polis: Satu kaji selidik mengenai keadaan lokap dan faktorfaktor penyumbang kepada kematian [Deaths in police custody a thematic study on lock-up conditions and factors contributing to the death.]. Suruhanjaya Hak Asasi Manusia Malaysia. Retrieved October 16, 2019, from www.suhakam.org.my

Tang, C., \& Chin, N. (2017). Building energy efficiency technical guideline for passive design. Building Sector Energy Efficiency Project (BSEEP), Malaysia. Retrieved June 7, 2020, from http://www.mgbc.org.my/ bseep-building-energy-efficiency-technical-guideline-for-passive-design/

Taweekun, J., \& Tantiwichien, A. U. W. (2013). Thermal comfort zone for Thai people. Engineering, 5, 525529. https://doi.org/10.4236/eng.2013.55062

Tharim, A. H. A., Munir, F. F. A., Samad, M. H. A., \& Mohd, T. (2018). A field investigation of thermal comfort parameters in green building index (GBI)-rated office buildings in Malaysia. International Journal of Technology, 8, 1588-1596. https://doi.org/10.14716/ijtech.v9i8.2763

Toe, D. H. C., \& Kubota, T. (2013). Development of an adaptive thermal comfort equation for naturally ventilated buildings in hot-humid climates using ASHRAE RP-884 database. Frontiers of Architectural Research, 2, 278-291. https://doi.org/10.1016/j.foar.2013.06.003

Webb, C. G. (1959). An analysis of some observations of thermal comfort in an equatorial climate. British Journal of Industrial Medicine, 16, 297-310. https://doi.org/10.1136/oem.16.4.297

Wong, N. H., \& Khoo, S. S. (2003). Thermal comfort in classrooms in the tropics. Energy and Buildings, 35, 337-351. https://doi.org/10.1016/S0378-7788(02)00109-3

Wong, N. H., Tan, E., \& Adelia, A. S. (2020). Utilization of natural ventilation for hot and humid Singapore. In Building in Hot and Humid Regions (pp. 165-184). Springer.https://doi.org/10.1007/978-981-13-7519-4_8

World Meteorological Organisation. (2020). World weather. World Meteorological Organisation. Retrieved July 27, 2020, from https://worldweather.wmo.int/en/home.html

Xue, F., Gou, Z., \& Lau, S. (2016). Human factors in green office building design: The impact of workplace green features on health perceptions in high-rise high-density asian cities. Sustainability, 8(11), Article 1095. https://doi.org/10.3390/su8111095

Yang, T., \& Clements-Croome, D. J. (2018). Natural ventilation in built environment. In Encyclopedia of Sustainability Science and Technology (pp. 1-35). Springer Science + Business Media. https://doi. org/10.1007/978-1-4939-2493-6_488-3

Yusoff, W. F. M., \& Mohamed, M. F. (2017). Building energy efficiency in hot and humid climate. In Encyclopedia of Sustainable Technologies (pp. 159-168). Elsevier. https://doi.org/10.1016/B978-0-12409548-9.10191-5

Zaharin, Z., Nordin, J., \& Shukri, S. M. (2019, November 6-7). Added value to security building design case study: Police Station in Malaysia. In ICRP 2019 4th International Conference on Rebuilding Place (pp. 362-373). Penang, Malaysia. https://doi.org/10.15405/epms.2019.12.35 
Bismiazan Abd. Razak, Mohd. Farid Mohamed, Wardah Fatimah Mohammad Yusoff and Mohd. Khairul Azhar Mat Sulaiman

Zain, Z. M., Taib, M. N., \& Baki, S. M. S. (2007). Hot and humid climate: Prospect for thermal comfort in residential building. Desalination, 209, 261-268. https://doi.org/10.1016/j.desal.2007.04.036

Zhang, G., Zheng, C., Yang, W., Zhang, Q., \& Moschandreas, D. J. (2007). Thermal comfort investigation of naturally ventilated classrooms in a subtropical region. Indoor and Built Environment, 16(2), 148-158. https://doi.org/10.1177/1420326X06076792 